\title{
Plant Species in a tract of insular Atlantic Forest in Ilhabela (SP): Floristics, photographic documentation, and identification keys of arboreal dicotyledons based on vegetative characteristics
}

\author{
Andrea Garafulic Aguirre ${ }^{1 *} \mathbb{D}^{-}$, Juliana Teixeira ${ }^{1}$, João Paulo Fernandes Zorzanelli ${ }^{3}$, Gabriel Dalla Colletta ${ }^{2}$ \\ \& Daniela Sampaio ${ }^{4}$ \\ ${ }^{1}$ Universidade Estadual Paulista Júlio de Mesquita Filho, Departamento de Biologia Vegetal, \\ Rio Claro, SP, Brasil \\ ${ }^{2}$ Universidade Estadual de Campinas, Departamento de Biologia vegetal, Campinas, SP, Brasil \\ ${ }^{3}$ Universidade Federal do Espírito Santo, Departamento de Ciências Florestais e da Madeira, \\ Jerônimo Monteiro, ES, Brasil \\ ${ }^{4}$ Universidade Estadual Júlio de Mesquita Filho, Departamento de Zoologia e Botânica, \\ São José do Rio Preto, SP, Brasil \\ *Corresponding author: Andrea Garafulic Aguirre, e-mail: deia.aguirre@gmail.com
}

AGUIRRE, A. G., TEIXEIRA, J., ZORZANELli, J. P. F., COLlETTA, G. D., SAMPAIO, D. Plant Species in a tract of insular Atlantic Forest in Ilhabela (SP): Floristics, photographic documentation, and identification keys of arboreal dicotyledons based on vegetative characteristics. Biota Neotropica. 18(4): e20170497. http://dx.doi.org/10.1590/1676-0611-BN-2017-0497

\begin{abstract}
The Ilhabela State Park (PEIb, for Parque Estadual Ilhabela in Portuguese) - located between $23^{\circ} 46^{\prime}$ $28^{\prime \prime}$ south latitude and $45^{\circ} 21^{\prime} 20^{\prime \prime}$ west latitude - is responsible for the conservation of one of the most important, and most devastated, fragments of insular Atlantic Forest. To catalog the arboreal species along the trails of the Conservation Unit, and to provide a practical instrument to facilitate the recognition of these species, we aimed with this work to conduct a floristic and photographic survey of distinct life forms and create an identification key for arboreal dicotyledonous species based on vegetative characters. We cataloged 123 species belonging to 99 genera and 46 botanical families. The best-represented families were Rubiaceae (15 spp.), Fabaceae (10), Piperaceae (10), Myrtaceae (8), Melatomataceae (7) and Lauraceae (7). We found three species threatened with extinction, two new occurrences for the state of São Paulo, and one plant species new to science, demonstrating the floristic importance of the region. We developed three vegetative dichotomous identification keys: to species with compound leaves; simple and opposite leaves; and alternate simple leaves. The dichotomous keys presents 97 arboreal species, distributed among 37 families, and was based on vegetative characters such as phyllotaxis, composition and shape of the limbus, presence or absence of stipules, exudate, lenticels, indument, glands and dots. We also elaborated a photographic board with 118 species as a supplementary material to support the use of the identification key.

Keywords: Insular environments, dichotomous keys, Atlantic Forest, Ilhabela State Park.

\section{Espécies vegetais em um trecho de Mata Atlântica insular em Ilhabela (SP): Florística, documentação fotográfica e chaves de identificação de dicotiledôneas arbóreas baseadas em características vegetativas}

Resumo: O Parque Estadual de Ilhabela - PEIb (23 46' e 28" de latitude sul e $45^{\circ} 21^{\prime}$ 20" de latitude oeste) é responsável pela conservação de um dos mais importantes e devastados fragmentos de Mata Atlântica insular. Como forma de listar as espécies arbóreas nas trilhas da Unidade de Conservação e fornecer um instrumento prático para auxiliar no reconhecimento dessas espécies, objetivamos nesse trabalho realizar um levantamento florístico e fotográfico com distintas formas de vida para elaborar uma chave de identificação das espécies de Dicotiledôneas arbóreas com base em caracteres vegetativos. Listamos 123 espécies, presentes em 99 gêneros e 46 famílias botânicas. As famílias mais bem representadas foram Rubiaceae (15 spp.), Fabaceae (10), Piperaceae 
Aguirre, A.G. et al.

(10), Myrtaceae (8), Melatomataceae (7) e Lauraceae (7). Encontramos três espécies ameaçadas de extinção, duas novas ocorrências para o estado de São Paulo e uma nova espécie de planta para a ciência, demonstrando a importância florística do local. Elaboramos três chaves dicotômicas vegetativas de identificação sendo elas: para espécies com folhas compostas; folhas simples e opostas; e folhas simples e alternas. As chaves apresentando 97 espécies arbóreas, distribuídas em 37 famílias, baseadas em caracteres vegetativos tais como filotaxia, composição e formato do limbo, presença ou ausência de estípulas, exsudado, lenticelas, indumento, glândulas e pontuações. Nós também elaboramos pranchas fotográficas como um material suplementar de auxílio à utilização da chave de identificação.

Palavras-chave: Ambientes insulares, chaves dicotômicas, Floresta Atlântica, Parque Estadual de Ilhabela.

\section{Introduction}

Large-scale conservation planning is based on information about vascular plants, because they provide the structure for ecosystems (Kreft \& Jetz 2007, Marques 2015). This information depends on taxonomic studies and cataloging of flora, primarily at local and regional scales, and is then extrapolated to understand global patterns of distribution (Kreft et al. 2008, Myers et al. 2000).

Within this perspective, insular environments are significant for their importance to the conservation of biological diversity around the world, as a quarter of all known vascular plant species are endemic to these ecosystems (Kier et al. 2009). As biodiversity hotspots, they are extremely vulnerable to human activities, especially concerning biological invasions and climate changes (Braje et al. 2017, Hofman \& Rick 2017, Nogue et al. 2017), which leads to biodiversity loss at an accelerated rate relative to the pace of registration and documentation of species distribution and diversity (Kier et al. 2009, Kreft et al. 2008).

In Brazil, one of the centers of global priority for conservation (Brooks et al. 2006) and of vascular plant richness (IUCN 1997), this situation is grave, because vegetation is restricted to small landscape fragments, especially for the Brazilian Atlantic Forest (Ribeiro et al. 2009, Haddah et al. 2015), and many plant species still await formal description (Trias-Blasi \& Vorontsova 2015). According to the federal government's database on Brazilian biodiversity, Sistema de Informação sobre a Biodiversidade Brasileira (http://www.sibbr.gov.br/), only an estimated $11 \%$ of the nation's total biodiversity is known, and $1.821 \%$ of this total is represented by recorded species of angiosperms. However, there are few inventories of the biodiversity and stages of conservation of biota in geographic isolation (Gibson et al. 2017), such as the vegetation of the Ilhabela State Park (PEIb).

Among the more recent studies conducted in insular environments of southeastern Brazil, Nunes-Freitas and collaborators (2009) assessed the status of knowledge on the family Bromeliaceae in Ilha Grande, RJ; Ferreira et al. (2007) did a floristic survey covering several families on Franceses Island, Espírito Santo State; Kurtz et al. (2017) described the vascular flora and vegetation on Ilha Queimada Grande, São Paulo; and Bovini et al. (2014) studied the floristic diversity of the Ilhas Cagarras natural monument in Rio de Janeiro.

The creation of identification keys is instrumental in advancing the knowledge of Brazil's wide biodiversity while it still exists, being of fundamental importance to the knowledge of insular flora. As one of the recent concerns of scientists, these keys become even more relevant when based on vegetative morphological characteristics (Braz et al. 2004, Duarte 2003, Eltink et al. 2011, Rejmanek \& Brewer 2001, Urbanetz et al. 2010), because they present simplified information, making them fast and easy to use, and they do not depend mainly on one specific period of the year. Therefore, our objective was to create a dichotomous key based on vegetative characters, using the species collected in an archipelago-park that has $92 \%$ of its territory covered by native vegetation in different stages of conservation, and is the largest and most populous on the southeast coast of Brazil (Galetti et al. 2016), the Ilhabela State Park.

\section{Material and Methods}

We collected fertile botanical materials during semiannual field expeditions between 2012 and 2014, along three trails in the PEIb, in São Sebastião municipality, São Paulo (geographic coordinates $23^{\circ}$ $46^{\prime} 28^{\prime \prime}$ south latitude and $45^{\circ} 21^{\prime} 20^{\prime}$ " west latitude), ranging from 200 to $500 \mathrm{~m}$ in altitude. All fertile materials were photographed and incorporated into the collections Instituto Florestal (SPSF) and the Escola Superior de Agricultura Luiz de Queiroz (ESA) Herbariums (Acronyms according to Thiers 2017).

The trails where we collected the botanical materials are, specifically, the most vulnerable of the Conservation Unit due to the large volume of visitors. The names of these trails are "Cachoeira da Laje", "Três Tombos", "Praia dos Castelhanos" and "Cachoeira da Água Branca".

The studied areas are included in the category of Submontane Dense Ombrophilous Forest (IBGE, 2012), with stages of conservation varying from middle to advanced, usually presenting a closed canopy structure and three strata. Although these areas share the same vegetation formation, they present a configuration of differentiated species. This condition may be influenced by several factors such as variation in distinct soil types, slope, face and altitude. There is not much illegal logging in the park, but it suffers constant fires in the areas nearest the protective boundary zone, and hunting of wildlife occurs. The regional climate, according to the Köppen classification approximated for Brazil (Alvares et al. 2013), is classified as regional humid tropical without a dry season, type $C f b$, and with an average annual temperature of $18-22{ }^{\circ} \mathrm{C}$.

The taxonomic identification of the specimens was performed using specialized bibliography, consultation with specialists, and comparison 
with the collections deposited in the Instituto Florestal (SPSF) and the Escola Superior de Agricultura Luiz de Queiroz (ESA) Herbariums. The classification of the botanical families was made based on the system proposed by the APG IV (2016). Correct spelling, authorship and synonyms of the species were consulted in the online database Flora do Brasil 2020 under construction (http://floradobrasil.jbrj.gov. br/). The taxonomic key was elaborated after all the materials has been identified. We started observing each voucher species collected by us for elaborated an initial diagnosis for each specie, based on their main morphological characteristics, with terminologies following Harris \& Harris (1994), Souza \& Lorenzi (2008), Gonçalves \& Lorenzi (2007). After the initial diagnosis, we consulted in literature which main characteristics was used by taxonomists to describe the species. Than we compare these information with the initial diagnosis elaborated with the materials collected by us to create characteristic components for elaborate the vegetative dichotomous key. We consult the volumes in the Flora Fanerogâmica de São Paulo (Wanderley et al. 2002, 2003, 2005, 2009, 2012, 2016, Melhem et al. 2007) in all the steps to develop the identification key. Our last step to create the keys was separate the species into three main groups based on their phyllotaxis and leaf type. Thus, we made three keys: Key one representing the species with compound leaves; Key two for the species with opposite or subopposite simple leaves; and Key three for species with simple alternate leaves. In addition of the identification keys we produced photographic boards with general images of species sampled highlighting some morphological detail when necessary, as a detailed graphic material to support the use of the keys.

Threatened species have been categorized according to three distinct lists: a general list with international information, realized by the International Union for Conservation of Nature (IUCN); a national list that includes all threatened species in Brazil, the Brazilian Flora (CNCFlora); and a list of threatened species of the State of São Paulo (Resolution SMA n. 57/2016), which published the second revision of the official list of endangered flora species in the State of São Paulo.

\section{Results and Discussion}

We collected and identified 123 species (trees, shrubs, arborescent herbs, and herbs) distributed among 99 genera and 46 botanical families (Table 1, Figures 1 to 30). The best-represented families were Rubiaceae (15 spp.), Fabaceae (10), Piperaceae (10), Myrtaceae (8), Melatomataceae (7) and Lauraceae (7). This study's samples included one specie new to science, belonging to the genus Eugenia (Myrtaceae) (Mazine et al. in prep.); four species threatened with extinction (Phyllostemonodaphne geminiflora, Ficus pulchella, Trichilia casaretti and Nectandra barbellata - The IUCN Red List 2017); and two new occurrences for the state of São Paulo, Phyllostemonodaphne geminiflora and Simira glaziovii.

The botanical families with the greatest richness in our work are also among the best represented in coastal vegetation in the state of São Paulo, such as Fabaceae, Myrtaceae, Rubiaceae and Lauraceae (e.g. Rochelle et al. 2011, Prata et al. 2011). In the same way, most of the listed species presented a similar pattern being distributed along the Atlantic Forest, suggesting that the distance to the continental shelf does not constitute a physical barrier to the dispersion of these species.

New records of species and new descriptions from the state of São Paulo attest to the existence of knowledge gaps and low sample effort in some locations. This bias is also demonstrated for other states (e.g. Hassemer et al. 2015, Luber et al. 2016) and corresponds basically to the scarcity of floristic knowledge along the Atlantic Forest, where only $0.01 \%$ of its total area is sampled (Lima et al. 2015). This information is important to improve our understanding of geographic distribution and to provide references to species that are listed as "deficient data" (Zorzanelli et al. 2017), which are essential for planning and elaboration of conservation policies, especially in environments vegetation.

The three dichotomous key represented 97 tree species, distributed among 37 families. Two species have been incorporated in distinct keys: Esenbeckia grandiflora and Bauhinia forficata. E. grandiflora is considered a specie with compound leaves, but according to the observations in the field the specie shows alternate simple leaves. $B$. forficata exhibit compound leaves 2-leafleted, but can be confused with simple lobed leaves. For this reason, both species were added into the compound leaves key and alternate simple leaves key.

We also produced 30 boards with general images of 118 sampled species photographed, present on Figure 1 to 30 . The boards present photos of branches, flowers and/or fruits, in addition to details of the species fertile structures, such as inflorescence (i.e. Figure 4a, 5d, 19b) and fruits (i.e. Figure 6a, 13b, 24b, 30b).

Dichotomous keys based on fertile and vegetative morphological characters are widely disseminated, generally as the final product of cataloging local and regional flora. These tools are fundamental for research in different knowledge areas, because they require primarily the information generated by floristic studies (Eltink et al. 2011) and botanical collections. Although the keys have a broad functionality, their uses are limited by the acquisition of botanical materials in a fertile state, something common in rapid inventory works such as structural and phytosociological surveys. Therefore, the construction of dichotomous keys based only on vegetative characters represents an important tool for the knowledge of plant species where the samples do not have flowers and fruits, especially for local information, where the characters included can be clearly interpreted (Rejmánek \& Brewer 2000).

The publication of keys complemented by images of the details of fresh plants, in the laboratory or in situ, is an interesting proposal (Bittrich et al. 2012) and could improve the accuracy of correct plant species determination (Hawthorne et al. 2014). Ensuring and facilitating the process of plant species identification makes nature conservation strategies more effective.

Large islands tend to have high plant species richness, because they present different formations (Callado et al. 2009). Specifically, the archipelago of Ilhabela can be considered one of the leading insular samples of the Atlantic Forest, not only for its size and conservation, but also for its variation of altitudinal gradients and different formations. Therefore, efforts to catalog PEIb flora are necessary because we have little knowledge of this important vegetation until now. 
Aguirre, A.G. et al.

Table 1. List of species found, with their respective collection numbers in the herbariums of the Instituto Florestal (SPSF) and the Escola Superior de Agricultura Luiz de Queiroz (ESA); and information on the threatened species, obtained from the lists of the International Union for Conservation of Nature (IUCN), "Livro Vermelho da Flora do Brasil" - CNCFlora (Matinelli \& Moraes 2013) and the Secretariat of Environment of the State of São Paulo (SMA 057/2016), respectively. Conservation status levels: EN (In Danger); LC (Least Concern); VU (Vulnerable); DD (insuficiente data).

\begin{tabular}{|c|c|c|c|c|c|}
\hline Family/Scientific name & ESA & SPSF & IUCN & CNCFlora & SMA \\
\hline \multicolumn{6}{|l|}{ Acanthaceae } \\
\hline Aphelandra longiflora (Lindl.) Profice. & 128869 & 47329 & & & \\
\hline \multicolumn{6}{|l|}{ Anacardiaceae } \\
\hline Schinus terebinthifolius Raddi. & & 52235 & & & \\
\hline Guatteria australis A.St.-Hil. & & 47321 & & & \\
\hline \multicolumn{6}{|l|}{ Apocynaceae } \\
\hline Aspidosperma olivaceum Müll.Arg. & 128865 & 47370 & & & \\
\hline \multicolumn{6}{|l|}{ Aquifoliaceae } \\
\hline Monstera adansonii Schott. & 128877 & 47368 & & & \\
\hline \multicolumn{6}{|l|}{ Araliaceae } \\
\hline Dendropanax monogynus (Vell.) Seem. & 128828 & 47377 & & & \\
\hline \multicolumn{6}{|l|}{ Arecaceae } \\
\hline Geonoma elegans Mart. & & 47365 & & & \\
\hline \multicolumn{6}{|l|}{ Asteraceae } \\
\hline Eremanthus erythropappus (DC.) MacLeish. & & 47343 & & & \\
\hline Stifftia parviflora (Leandro.) D.Don. & & 47471 & & DD & \\
\hline Vernonanthura lindbergii (Baker.) H.Rob. & 128876 & & & DD & \\
\hline \multicolumn{6}{|l|}{ Cannabaceae } \\
\hline Trema micrantha (L.) Blume. & 128909 & 47473 & & & \\
\hline \multicolumn{6}{|l|}{ Celastraceae } \\
\hline Cheiloclinium cognatum (Miers.) A.C.Sm. & 128895 & & & & \\
\hline Monteverdia ardisiifolia (Reissek.) Biral. & 128829 & 47379 & & & \\
\hline Salacia grandifolia (Mart. ex Schult.) G.Don. & & 51841 & & & \\
\hline \multicolumn{6}{|l|}{ Chrysobalanaceae } \\
\hline Hirtella racemosa Lam. & & 51847 & & & \\
\hline \multicolumn{6}{|l|}{ Clethraceae } \\
\hline Clethra scabra Pers. & & 51855 & & & \\
\hline \multicolumn{6}{|l|}{ Clusiaceae } \\
\hline Clusia criuva Cambess. & & 52237 & & $\mathrm{LC}$ & \\
\hline
\end{tabular}


Continuation Table 1.

\begin{tabular}{|c|c|c|c|c|c|}
\hline Family/Scientific name & ESA & SPSF & IUCN & CNCFlora & SMA \\
\hline \multicolumn{6}{|l|}{ Commelinaceae } \\
\hline Dichorisandra hexandra (Aubl.) C.B.Clarke. & & 47347 & & & \\
\hline Scleria latifolia $\mathrm{Sw}$. & & 47316 & & & \\
\hline \multicolumn{6}{|l|}{ Elaeocarpaceae } \\
\hline \multicolumn{6}{|l|}{ Euphorbiaceae } \\
\hline Algernonia brasiliensis Baill. & & 51849 & & & \\
\hline Croton floribundus Spreng. & & 51853 & & & \\
\hline \multicolumn{6}{|l|}{ Fabaceae } \\
\hline Bauhinia forficata Link. & & 51852 & & & \\
\hline Inga striata Benth. & 128866 & 47364 & $\mathrm{LC}$ & & \\
\hline Machaerium nyctitans (Vell.) Benth. & 128875 & 47353 & & & \\
\hline Piptadenia gonoacantha (Mart.) J.F.Macbr. & 128913 & & & & \\
\hline Senna multijuga (Rich.) H.S.Irwin \& Barneby. & & 52234 & & & \\
\hline Swartzia langsdorffii Raddi. & & 51845 & & & \\
\hline Zollernia ilicifolia (Brongn.) Vogel. & & 51851 & & & \\
\hline \multicolumn{6}{|l|}{ Lamiaceae } \\
\hline Aegiphila integrifolia (Jacq.) Moldenke. & 128903 & 47452 & & & \\
\hline \multicolumn{6}{|l|}{ Lauraceae } \\
\hline Ocotea dispersa (Nees \& Mart.) Mez. & & 51844 & & & \\
\hline Phyllostemonodaphne geminiflora (Mez.) Kosterm. & & 50435 & $\mathrm{EN}$ & & \\
\hline \multicolumn{6}{|l|}{ Loganiaceae } \\
\hline Spigelia beyrichiana Cham. \& Schltdl. & & 47323 & & & \\
\hline Strychnos brasiliensis Mart. & & 52243 & & & \\
\hline \multicolumn{6}{|l|}{ Malvaceae } \\
\hline Eriotheca pentaphylla (Vell. \& K.Schum.) A.Robyns. & & 52241 & & & \\
\hline Quararibea turbinata (Sw.) Poir. & 128841 & 47376 & & & \\
\hline Luehea divaricata Mart. \& Zucc. & 128873 & 47319 & & & \\
\hline \multicolumn{6}{|l|}{ Melastomataceae } \\
\hline Leandra ionopogon (Mart.) Cogn. & 128855 & 47345 & & & \\
\hline Miconia cinnamomifolia (DC.) Naudin. & 128883 & 47315 & & & \\
\hline Miconia dodecandra Cogn. & 128888 & 47330 & & & \\
\hline Miconia fasciculata Gardner. & 128833 & 47346 & & & \\
\hline
\end{tabular}


Aguirre, A.G. et al.

Continuation Table 1.

\begin{tabular}{|c|c|c|c|c|c|}
\hline Family/Scientific name & ESA & SPSF & IUCN & CNCFlora & SMA \\
\hline Miconia tristis Spring. & 128826 & 47344 & & & \\
\hline Tibouchina clavata (Pers.) Wurdack. & 128905 & 47477 & & & \\
\hline \multicolumn{6}{|l|}{ Meliaceae } \\
\hline Cabralea canjerana (Vell.) Mart. & & 52236 & & & \\
\hline \multicolumn{6}{|l|}{ Moraceae } \\
\hline Ficus insipida Willd. & 128868 & 47313 & & & \\
\hline Ficus pulchella Schott. & & & VU & & \\
\hline Sorocea racemosa Gaudich. & & 47464 & & & \\
\hline \multicolumn{6}{|l|}{ Myrtaceae } \\
\hline Campomanesia guaviroba (DC.) Kiaersk. & & 47349 & & & \\
\hline Marlierea excoriata Mart. & 128852 & & & & \\
\hline Myrcia hebepetala DC. & & 52244 & & & \\
\hline Myrcia spectabilis DC. & & 47351 & & & \\
\hline Myrcia splendens (Sw.) DC. & & 47455 & & & \\
\hline \multicolumn{6}{|l|}{ Nyctaginaceae } \\
\hline Guapira opposita (Vell.) Reitz. & & 47348 & & & \\
\hline \multicolumn{6}{|l|}{ Ochnaceae } \\
\hline \multicolumn{6}{|l|}{ Olacaceae } \\
\hline \multicolumn{6}{|l|}{ Phytolaccaceae } \\
\hline \multicolumn{6}{|l|}{ Piperaceae } \\
\hline Peperomia pseudoestrellensis C.DC. & 128858 & 47336 & & & \\
\hline Peperomia urocarpa Fisch. \& C.A.Mey. & & 47338 & & & \\
\hline Piper arboreum Aubl. & 128845 & 47334 & & & \\
\hline Piper amplum Kunth. & 128879 & & & & \\
\hline Piper hispidum Sw. & 128836 & 47359 & & & \\
\hline Piper lepturum Kunth. & 128880 & 47310 & & & \\
\hline Piper morisonianum C.DC. & & 47360 & & & \\
\hline Piper rivinoides Kunth. & 128915 & 47468 & & & \\
\hline Piper solmsianum C.DC. & & 47361 & & & \\
\hline Piper umbellatum L. & & 47358 & & & \\
\hline \multicolumn{6}{|l|}{ Primulaceae } \\
\hline Myrsine coriacea (Sw.) R.Br. ex Roem. \& Schult. & 128871 & 47339 & & & \\
\hline Myrsine guianensis (Aubl.) Kuntze. & 128874 & 47357 & & & \\
\hline Myrsine venosa A.DC. & & 47322 & & & \\
\hline Stylogyne pauciflora Mez. & & 51850 & & & \\
\hline
\end{tabular}


Continuation Table 1.

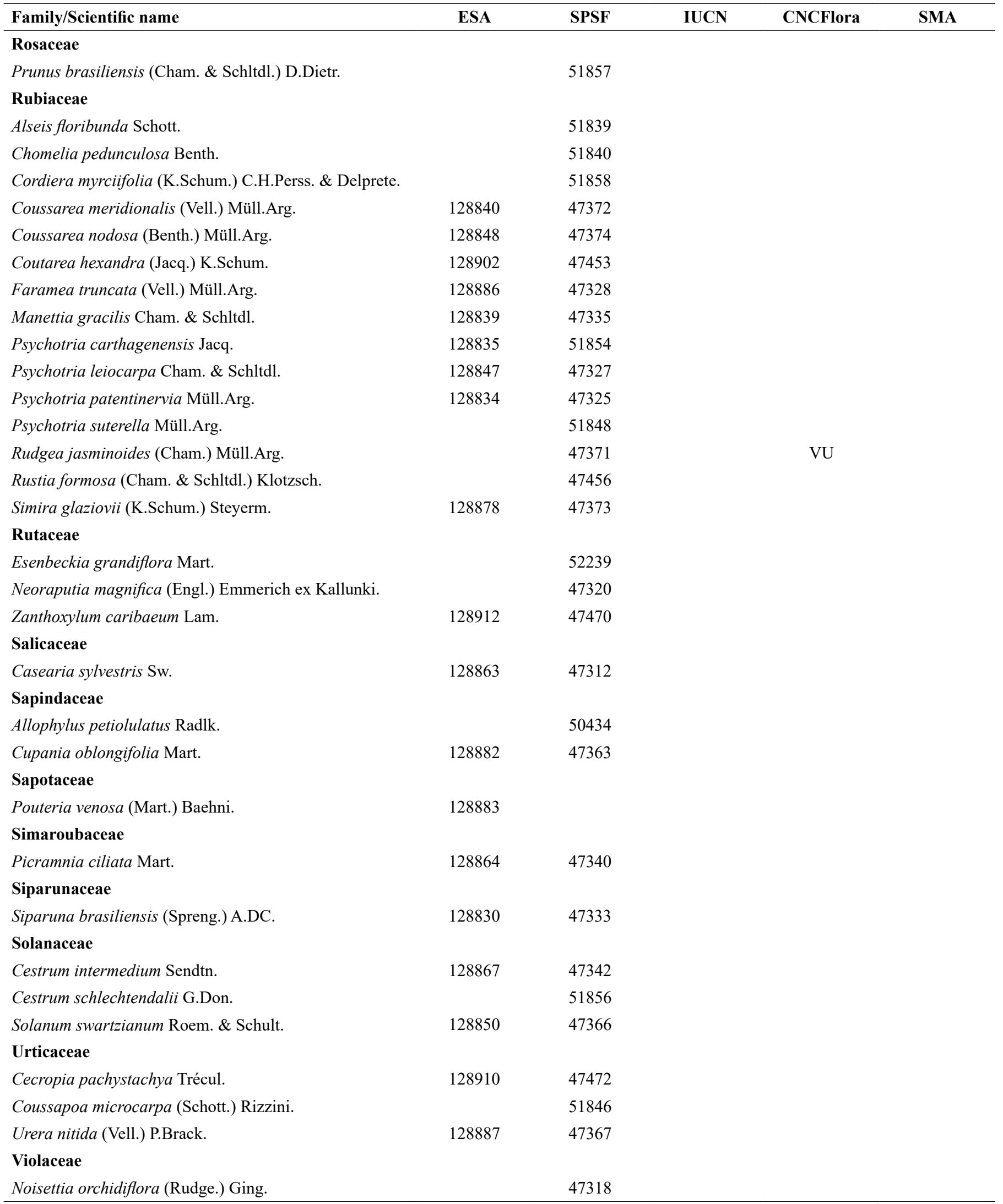




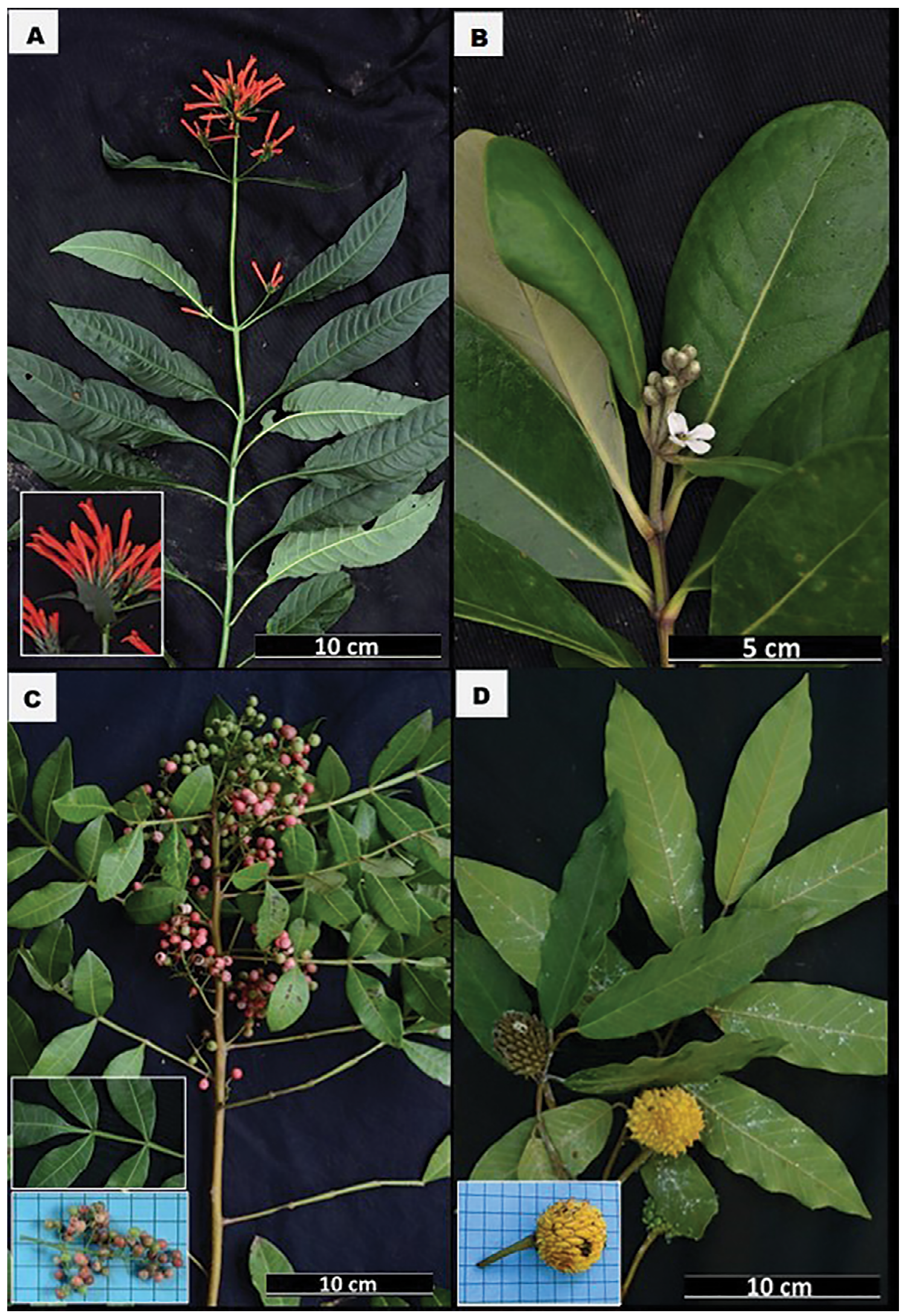

Figure 1. Acanthaceae: (A) Aphelandra longiflora, inflorescence in detail; (B) Avicennia schaueriana. Anacardiaceae: (C) Schinus terebinthifolius, details of the fruit and the winged compound leaf are highlighted. Annonaceae: (D) Annona dolabripetala, details of the fruit are highlighted. 


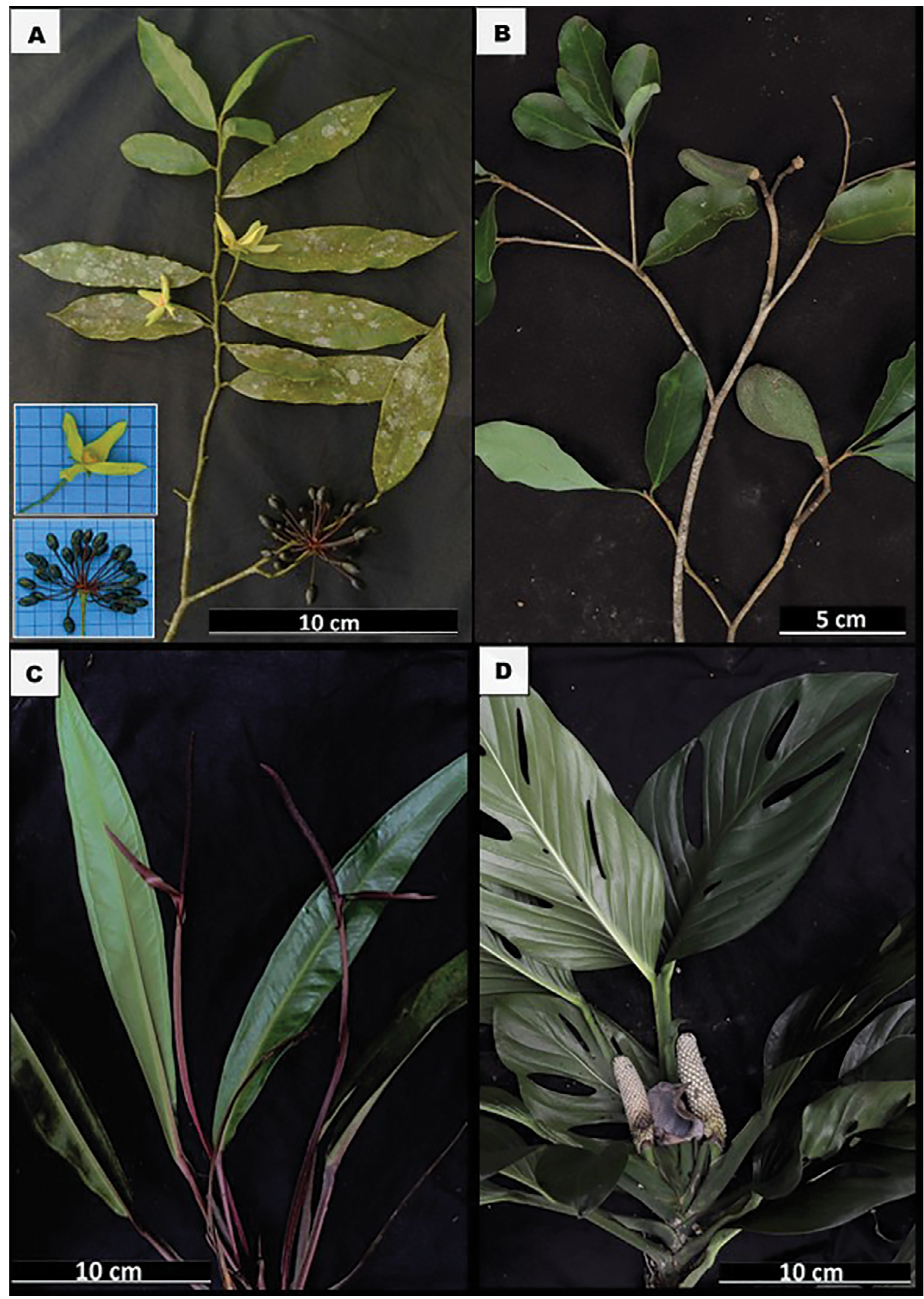

Figure 2. Annonaceae: (A) Guatteria australis, details of the inflorescence and fruits are highlighted. Apocynaceae: (B) Aspidosperma olivaceum. Araceae: (C) Anthurium sellowianum; (D) Monstera adansonii. 


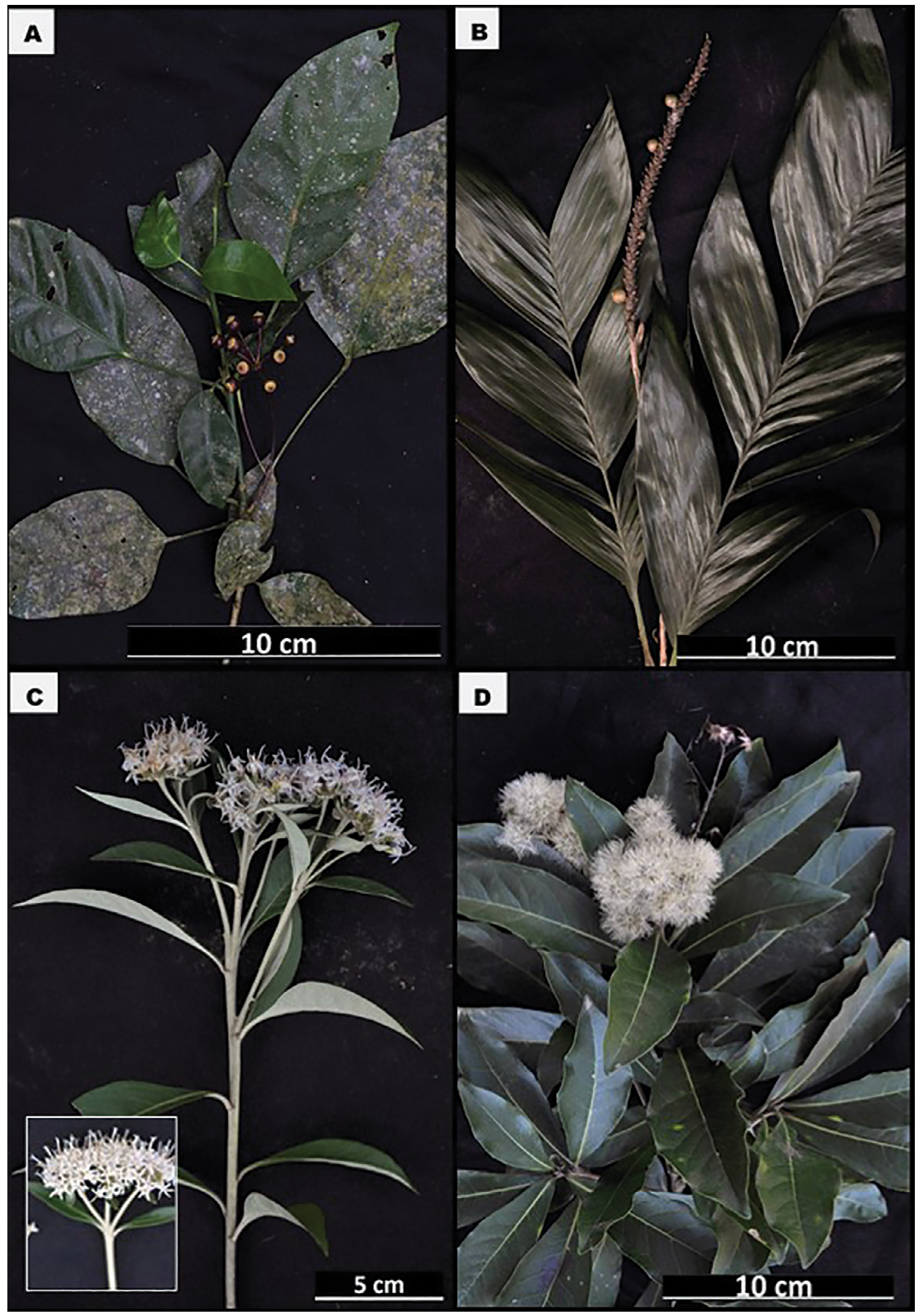

Figure 3. Araliaceae: (A) Dendropanax monogynus, details of the fruits are highlighted. Arecaceae: (B) Geonoma elegans. Asteraceae: (C) Eremanthus erythropappus, details of the inflorescence are hightlighted; (D) Stifftia parviflora. 

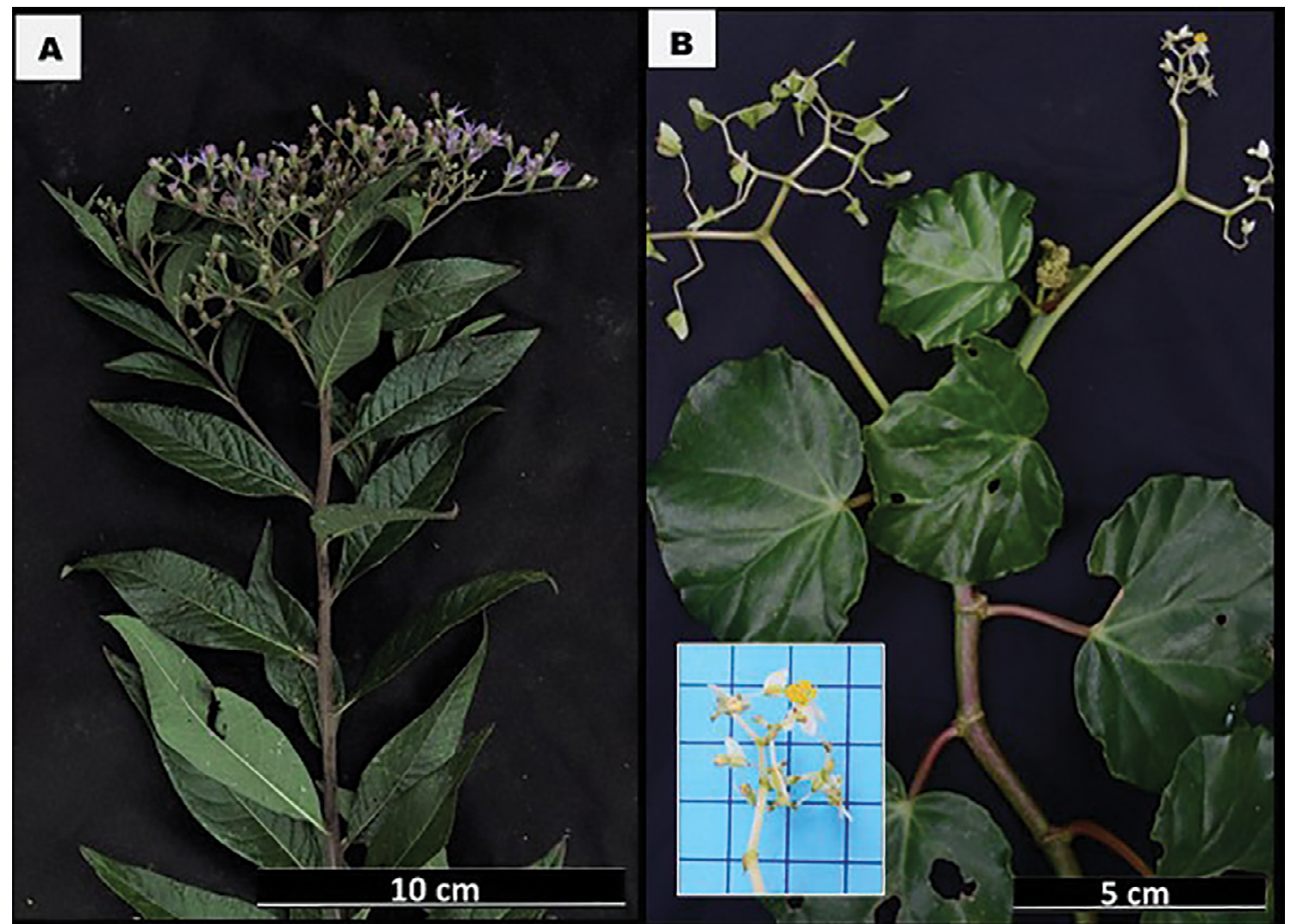

\section{C}

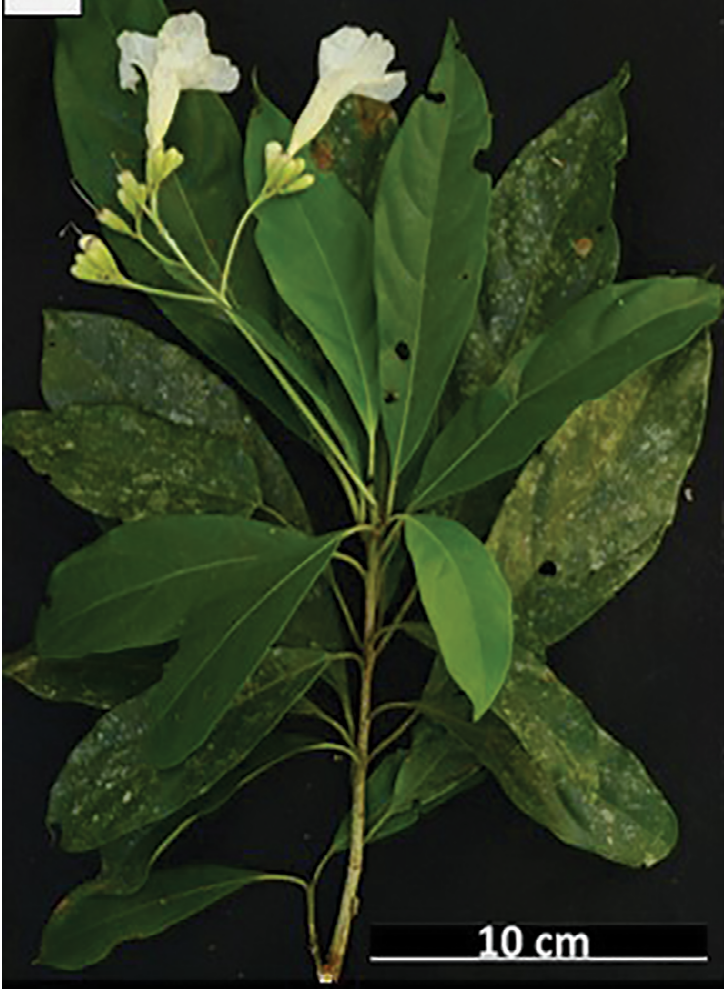

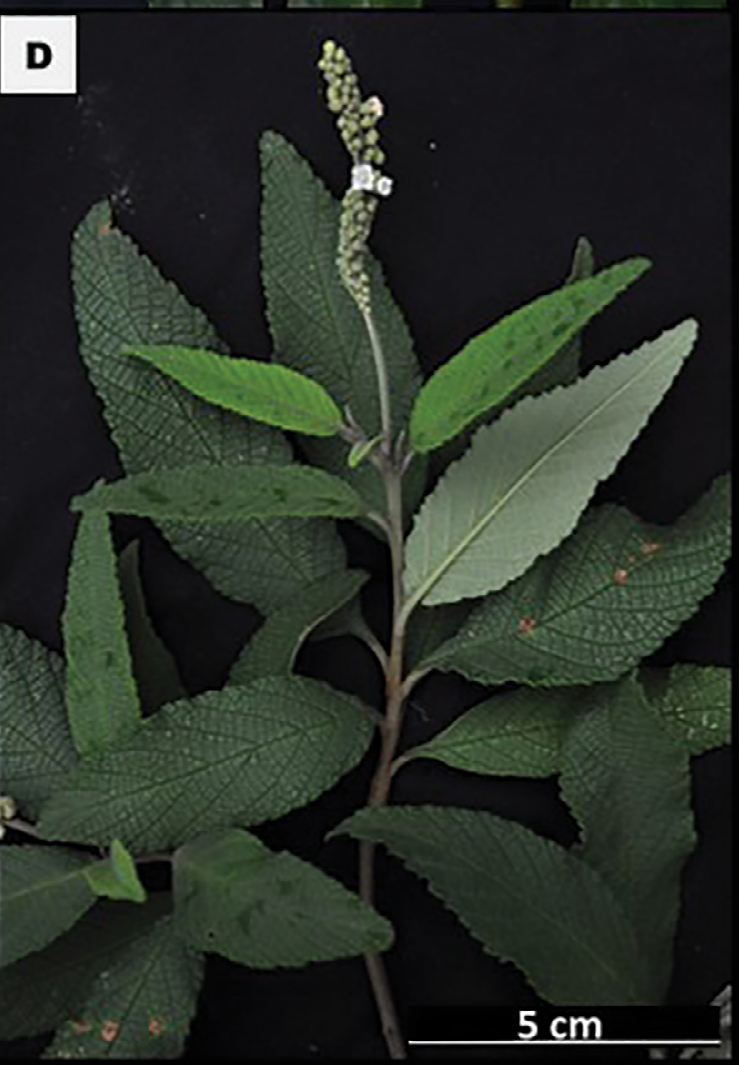

$5 \mathrm{~cm}$

Figure 4. Asteraceae: (A) Vernonanthura lindbergii. Begoniaceae: (B) Begonia convolvulacea, details of inflorescence are highlighted. Boraginaceae: (C) Cordia taguahyensis; (D) Varronia curassavica. 


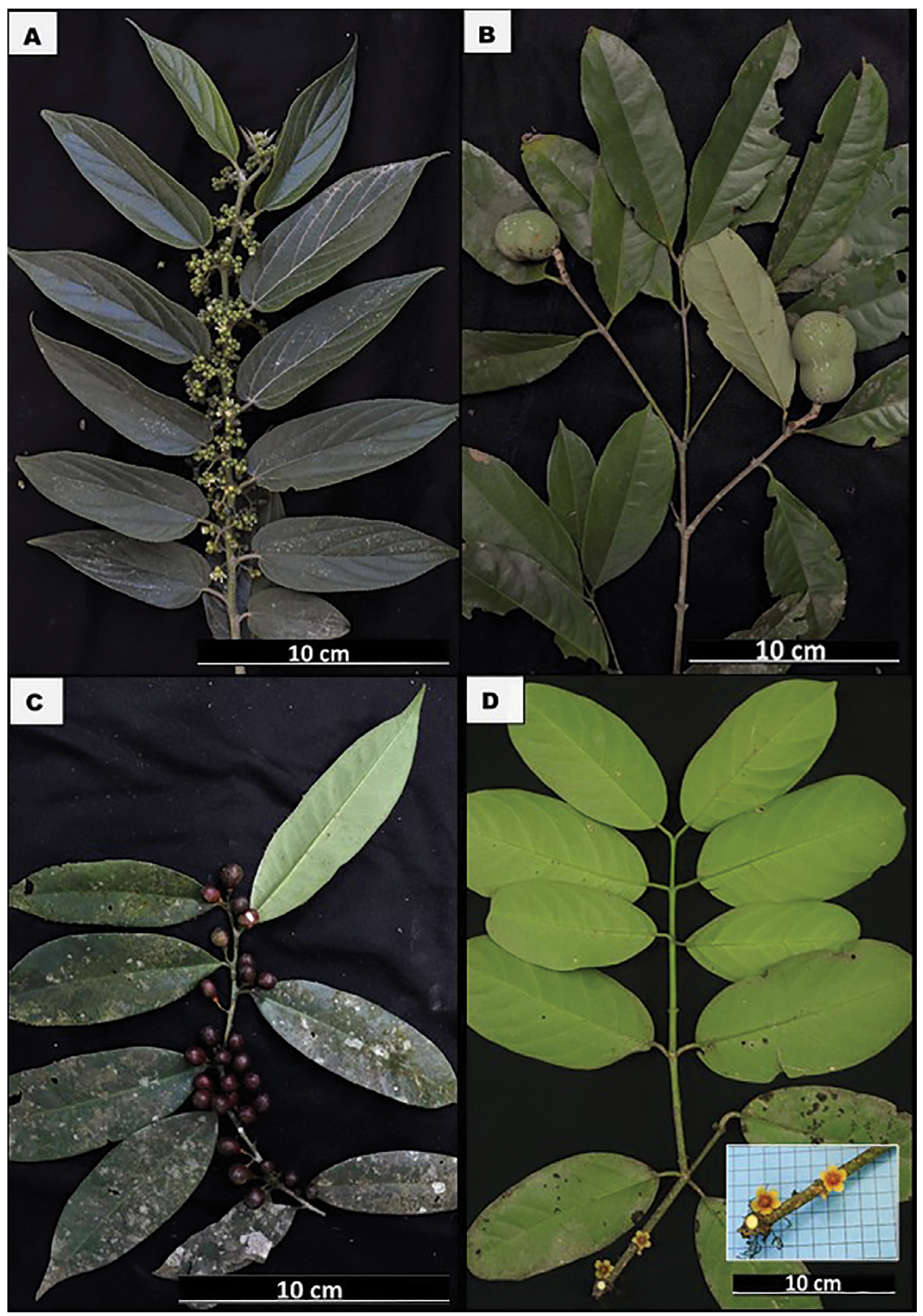

Figure 5. Cannabaceae: (A) Trema micrantha. Celastraceae: (B) Cheiloclinium cognatum; (C) Monteverdia ardisiifolia; (D) Salacia grandiflora, details of the inflorescence are highlighted. 

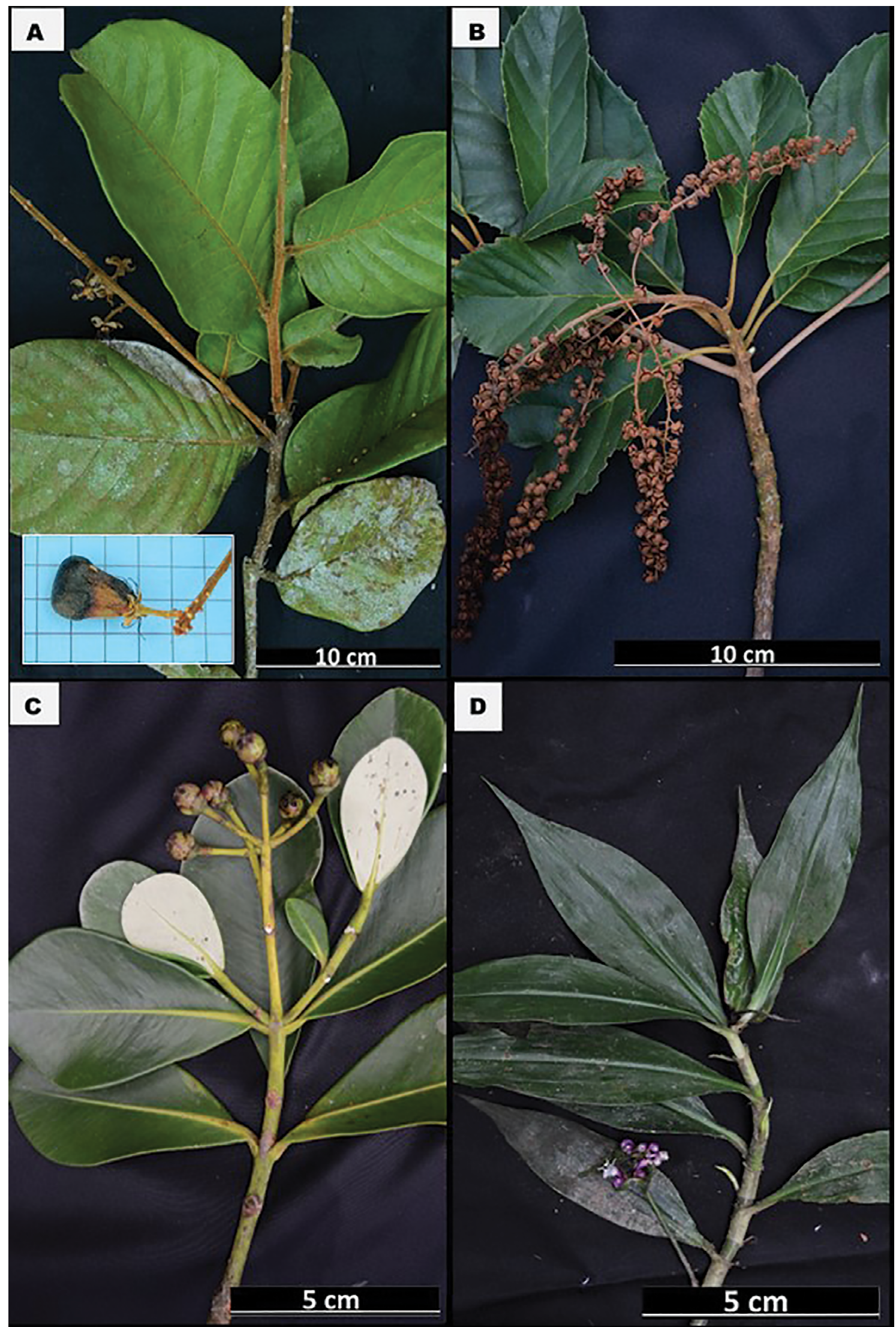

Figure 6. Chrysobalanaceae: (A) Hirtella racemosa, details of the fruit are highlighted. Clethraceae: (B) Clethra scabra. Clusiaceae: (C) Clusia criuva. Commelinaceae: (D) Dichorisandra hexandra. 


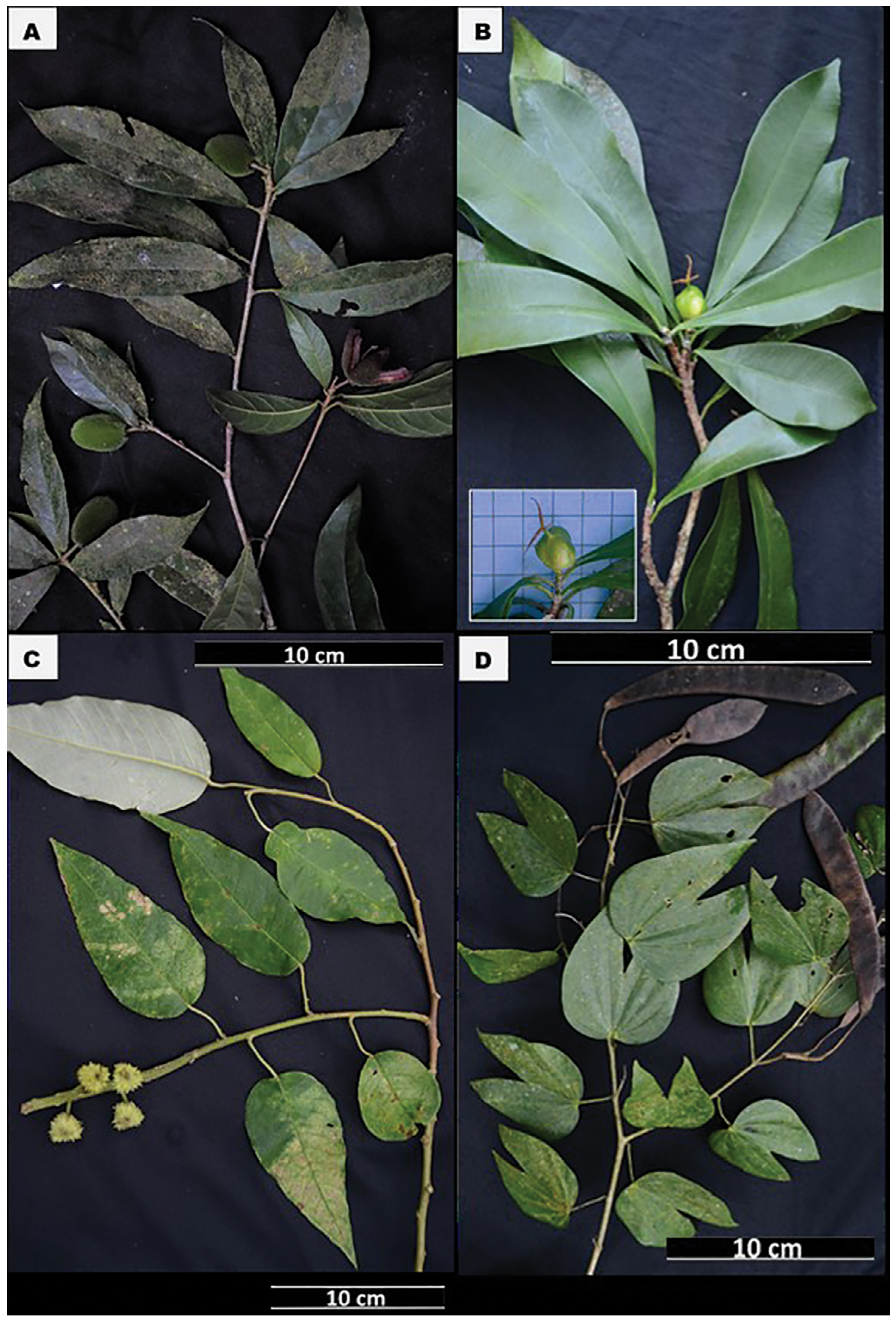

Figure 7. Elaeocarpaceae: (A) Sloanea hirsuta. Euphorbiaceae: (B) Algernonia brasiliensis, details of the fruit are highlighted. Euphorbiaceae: (C) Croton floribundus. Fabaceae: (D) Bauhinia forficata. 


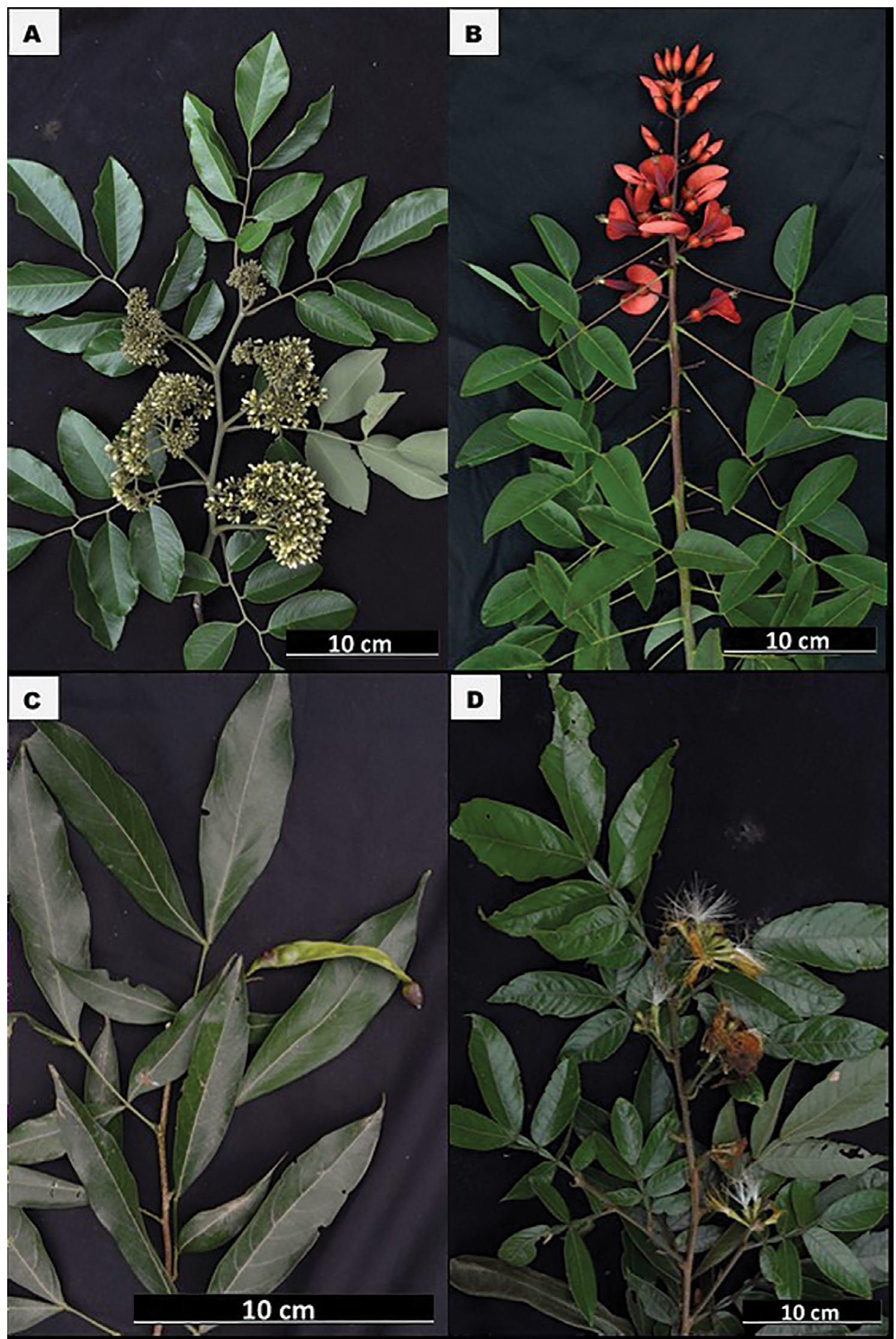

Figure 8. Fabaceae: (A) Dalbergia frutescens; (B) Erythrina crista-galli; (C) Inga marginata; (D) Inga striata. 


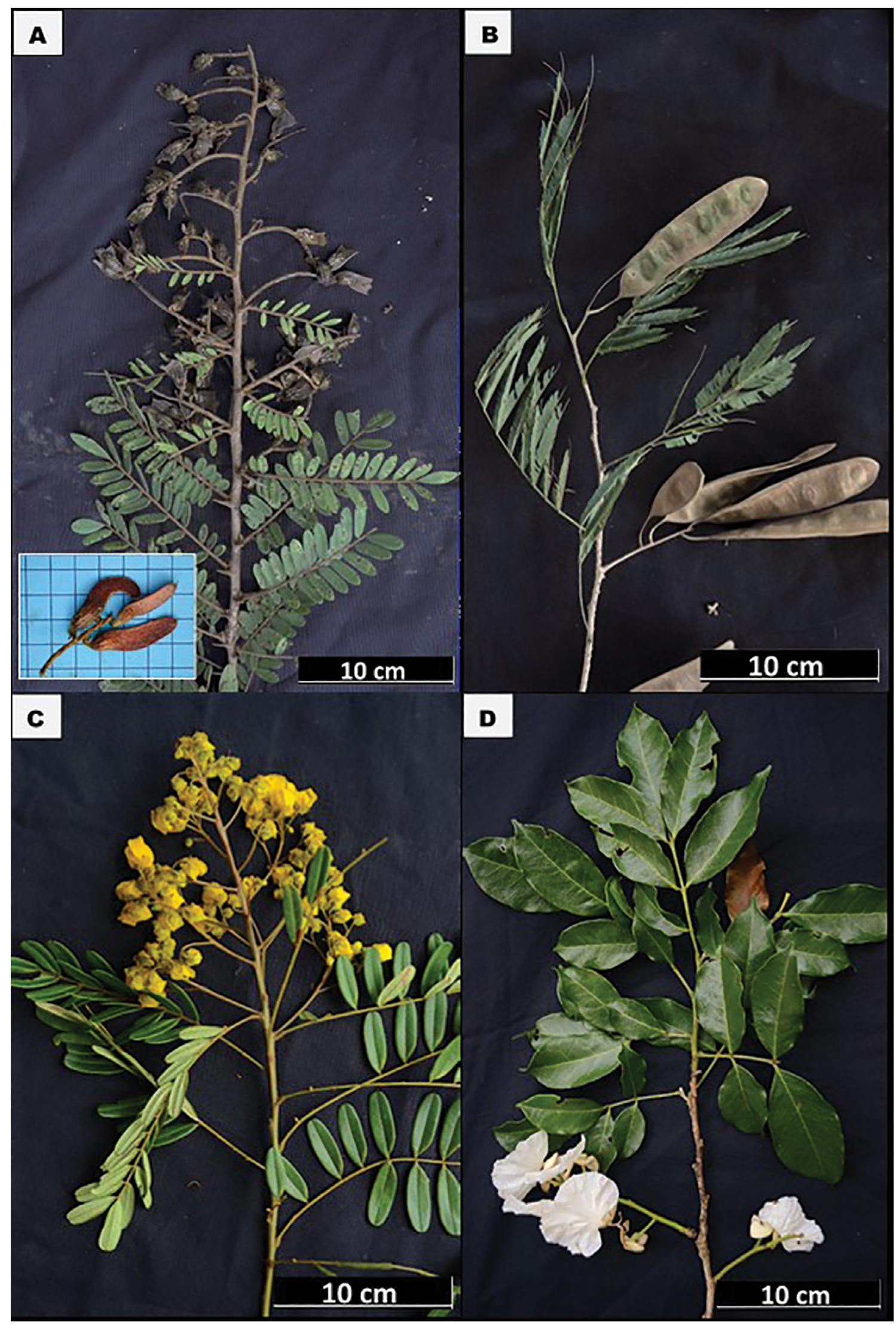

Figure 9. Fabaceae: (A) Machaerium nyctitans, details of the fruits are highlighted; (B) Piptadenia gonoacantha; (C) Senna multijuga; (D) Swartzia langsdorffii. 


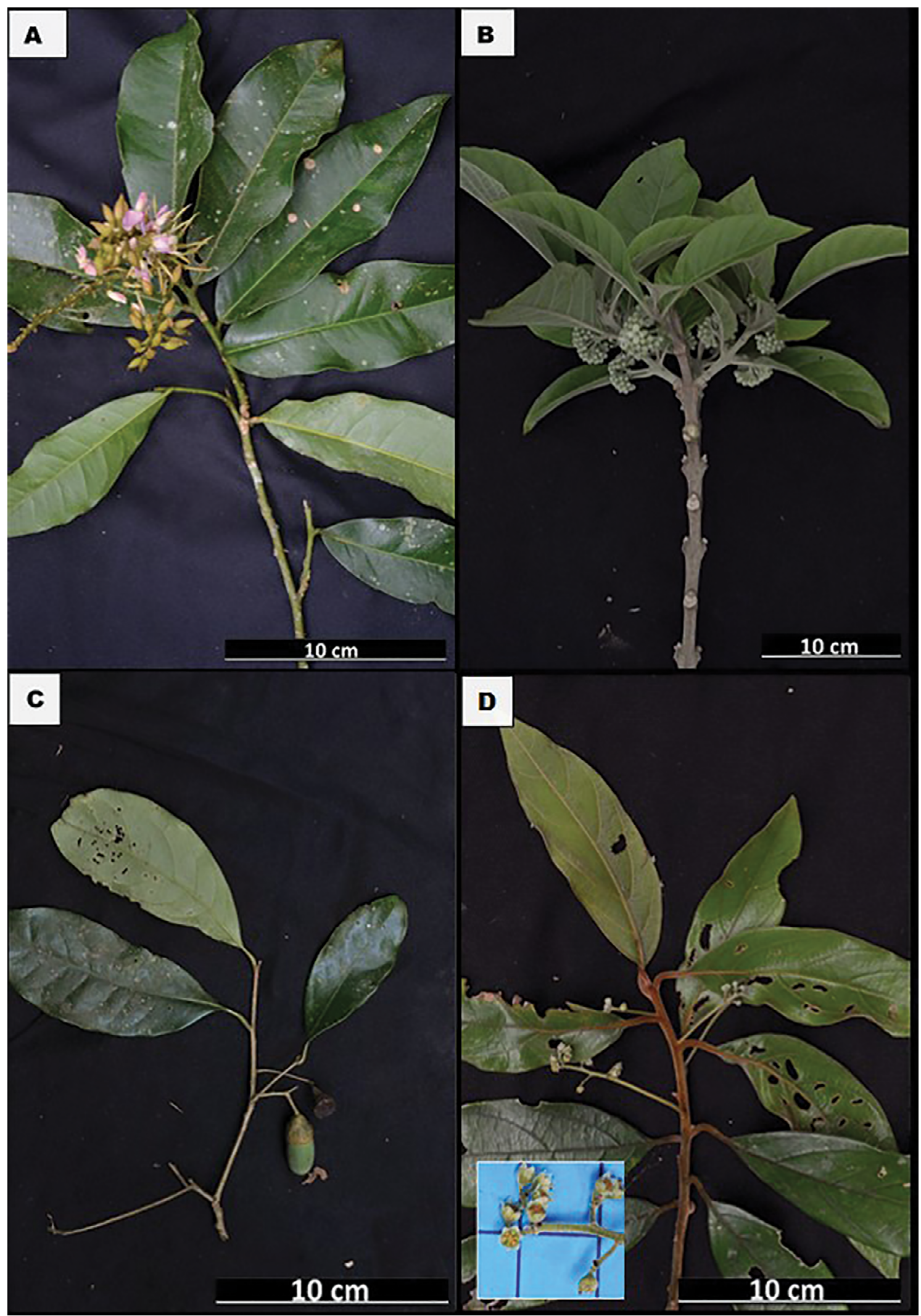

Figure 10. Fabaceae: (A) Zollernia ilicifolia. Lamiaceae: (B) Aegiphila integrifolia. Lauraceae: (C) Aniba viridis; (D) Endlicheria paniculata, details of the inflorescence are hightlighted. 

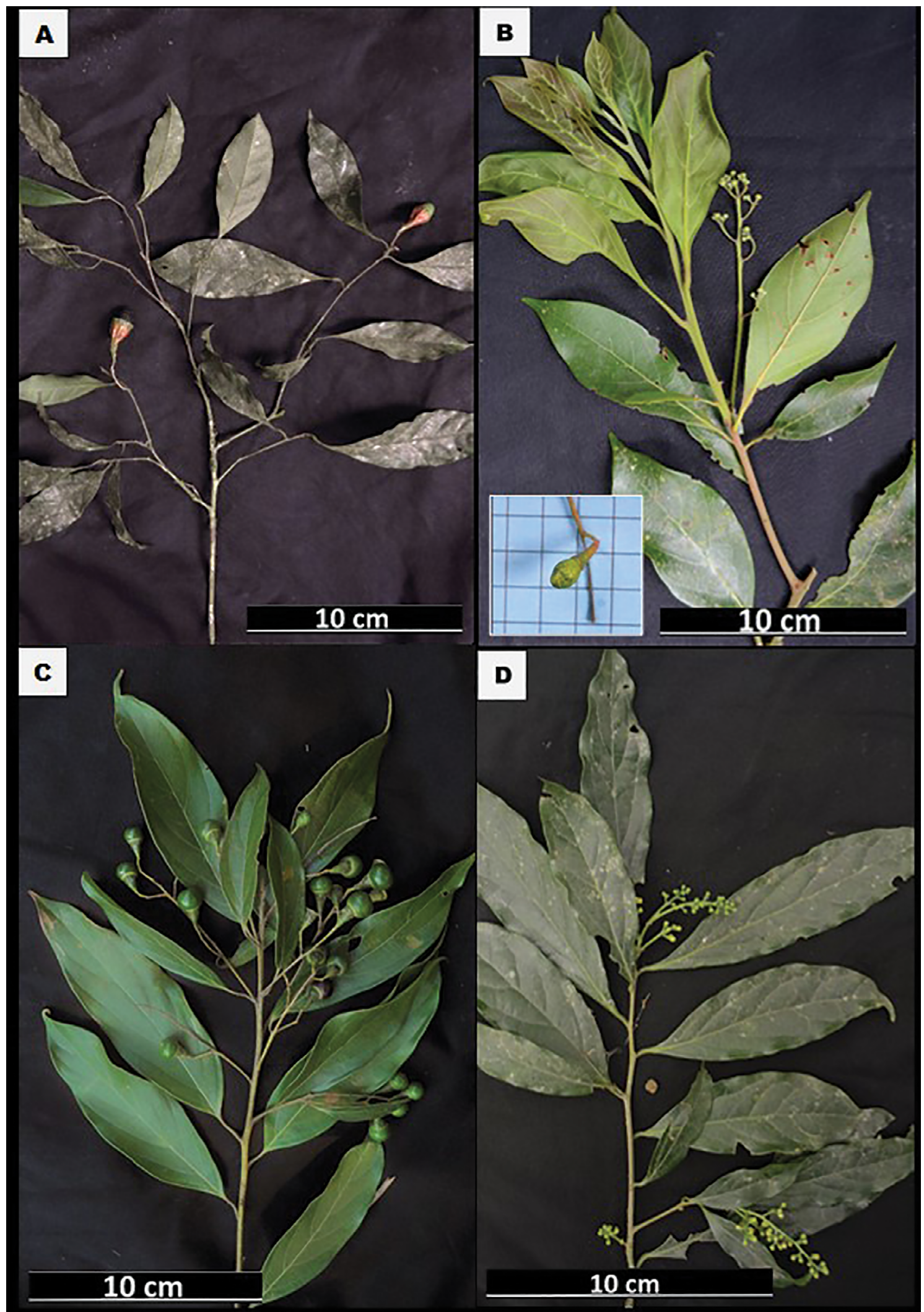

Figure 11. Lauraceae: (A) Licaria armeniaca; (B) Nectandra barbellata, details of the fruit are hightlighted; (C) Nectandra membranacea; (D) Ocotea dispersa. 


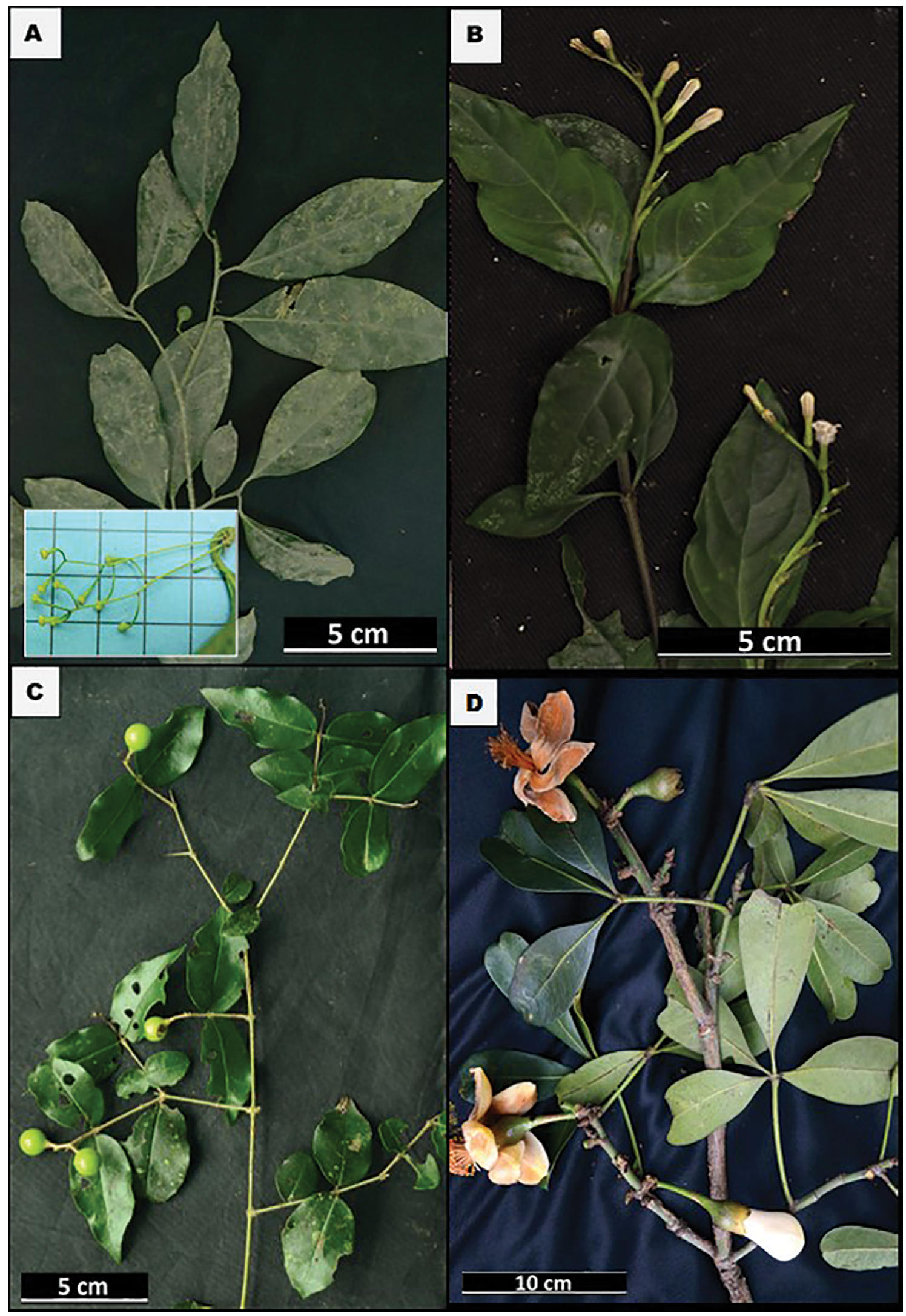

Figure 12. Lauraceae: (A) Phyllostemonodaphne geminiflora, details of the inflorescence are hightlighted. Loganiaceae: (B) Spigelia beyrichiana; (C) Strychnos brasiliensis. Malvaceae: (D) Eriotheca pentaphylla. 


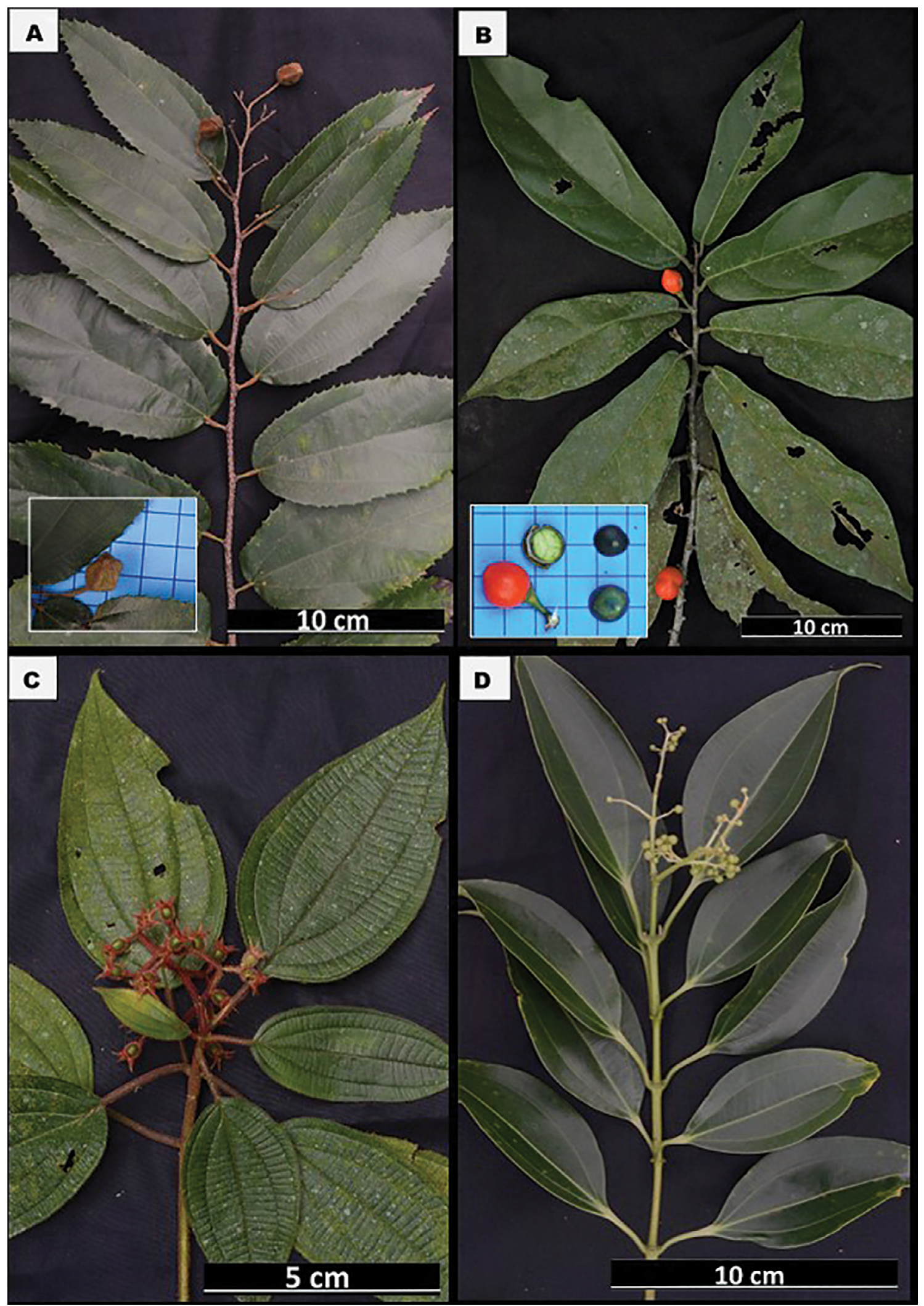

Figure 13. Malvaceae: (A) Luehea divaricata, details of the fruits are highlighted; (B) Quararibea turbinata, details of the fruits are highlighted. Melastomataceae: (C) Leandra ionopogon; (D) Miconia cinnamomifolia . 


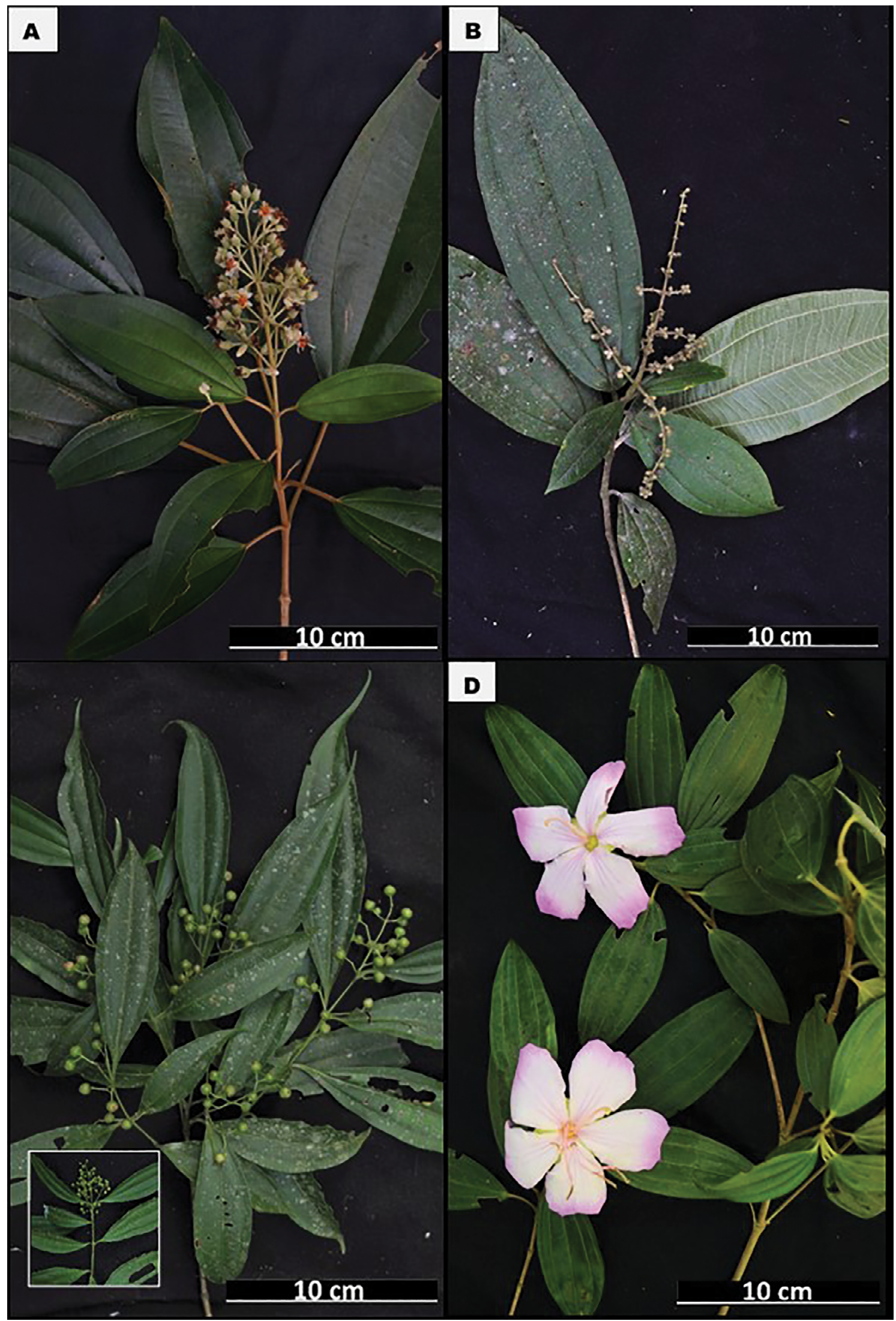

Figure 14. Melastomataceae: A) Miconia dodecandra; (B) Miconia fasciculata; (C) Miconia tristis, details of the fruits are highlighted; (D) Tibouchina pulchra. 


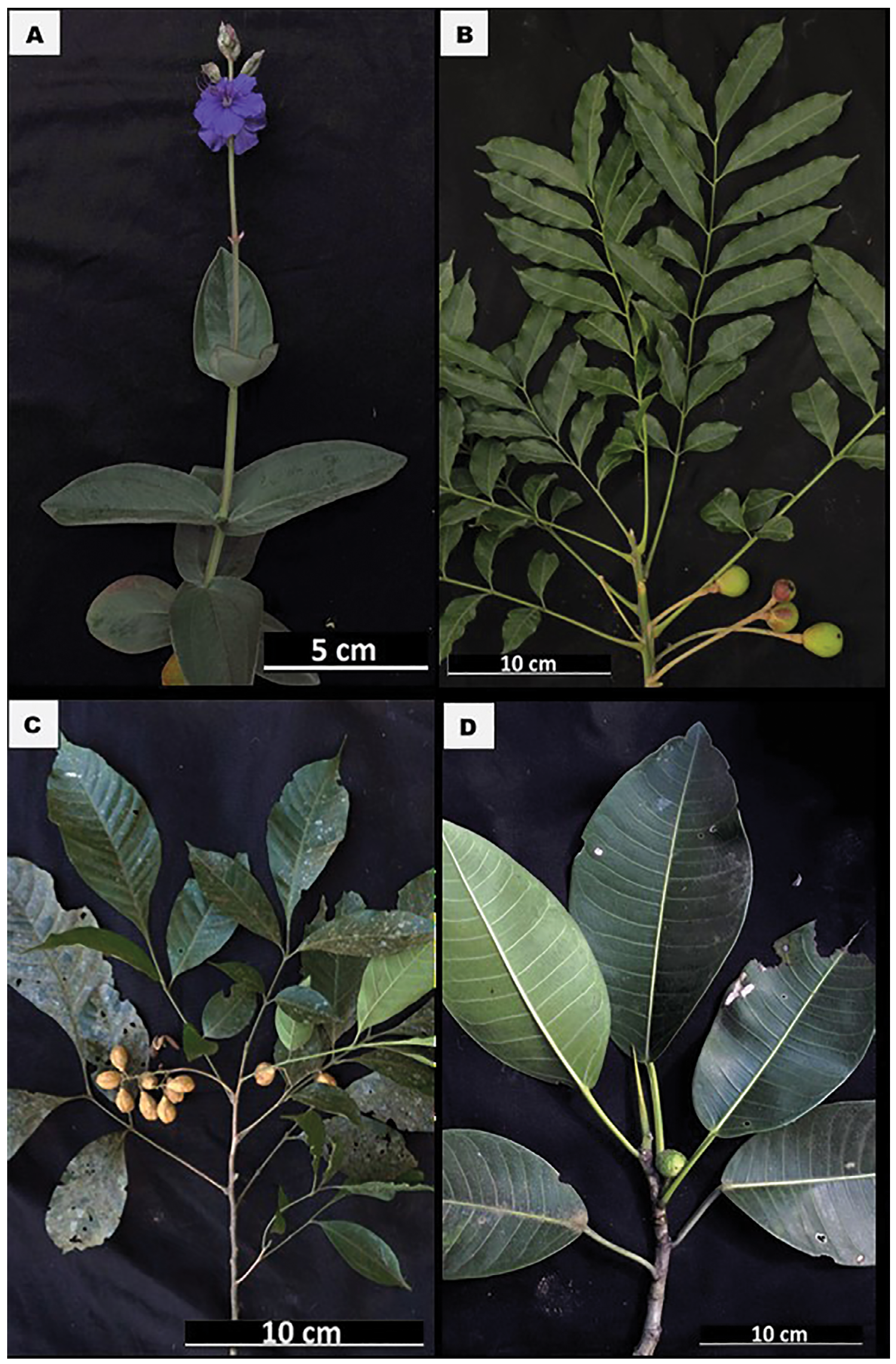

Figure 15. Melastomataceae: (A) Tibouchina clavata. Meliaceae: (B) Cabralea canjerana;(C) Trichilia casaretti. Moraceae: (D) Ficus insipida. 


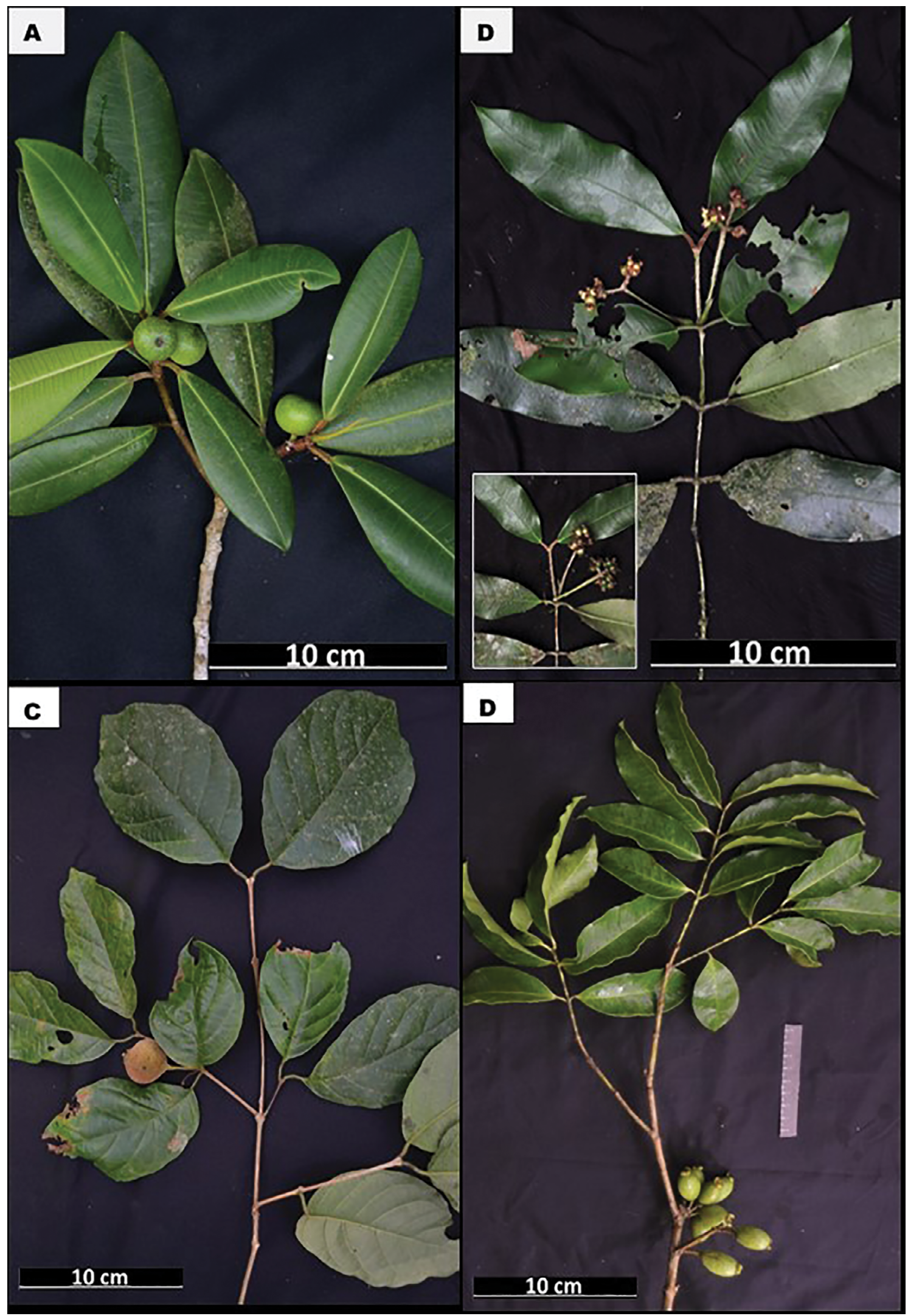

Figure 16. Moraceae: (A) Ficus pulchella. Myrtaceae: (B) Calyptranthes lanceolata, details of the fruits are highlighted; (C) Campomanesia guaviroba; (D) Eugenia fusca. 


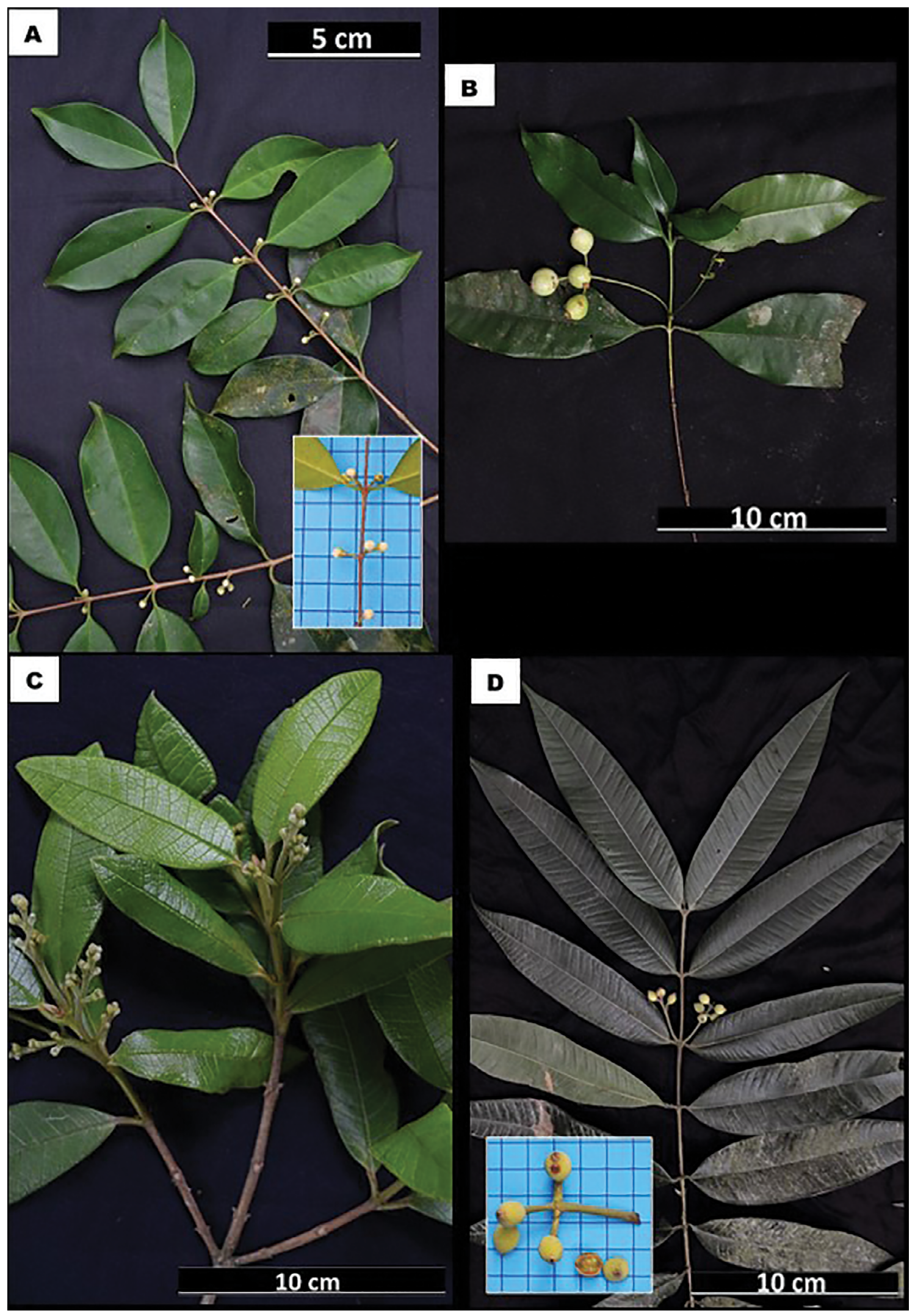

Figure 17. Myrtaceae: (A) Eugenia sp. (Mazine et al. in prep.), details of the fruits are highlighted; (B) Marlierea excoriota; (C) Myrcia hebepetala, details of the fruits are highlighted; (D) Myrcia spectabilis. 


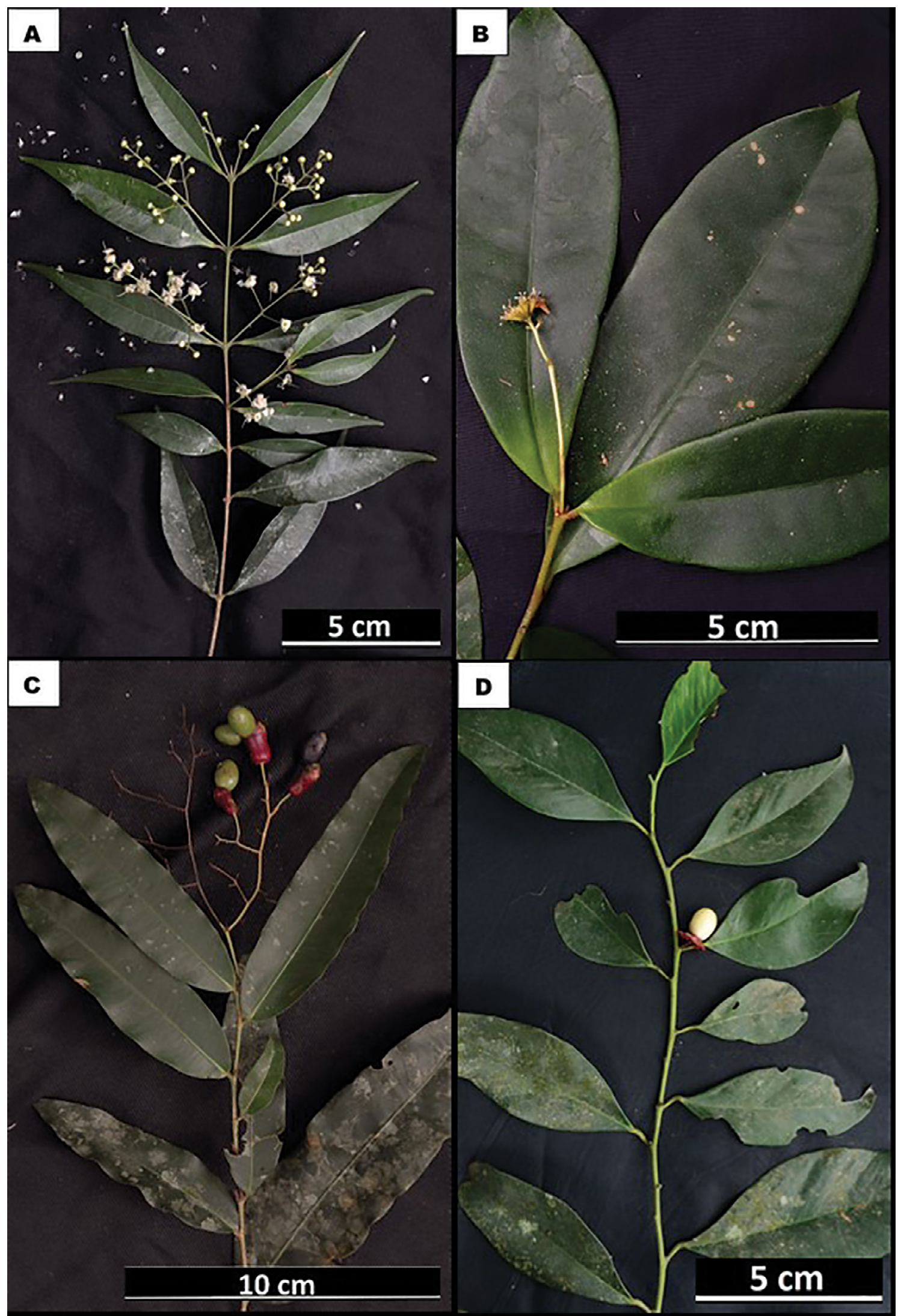

Figure 18. Myrtaceae: (A) Myrcia splendens. Nyctaginaceae: (B) Guapira opposita. Ochnaceae: (C) Ouratea parviflora; Olacaceae: (D) Heisteria silvianii. 


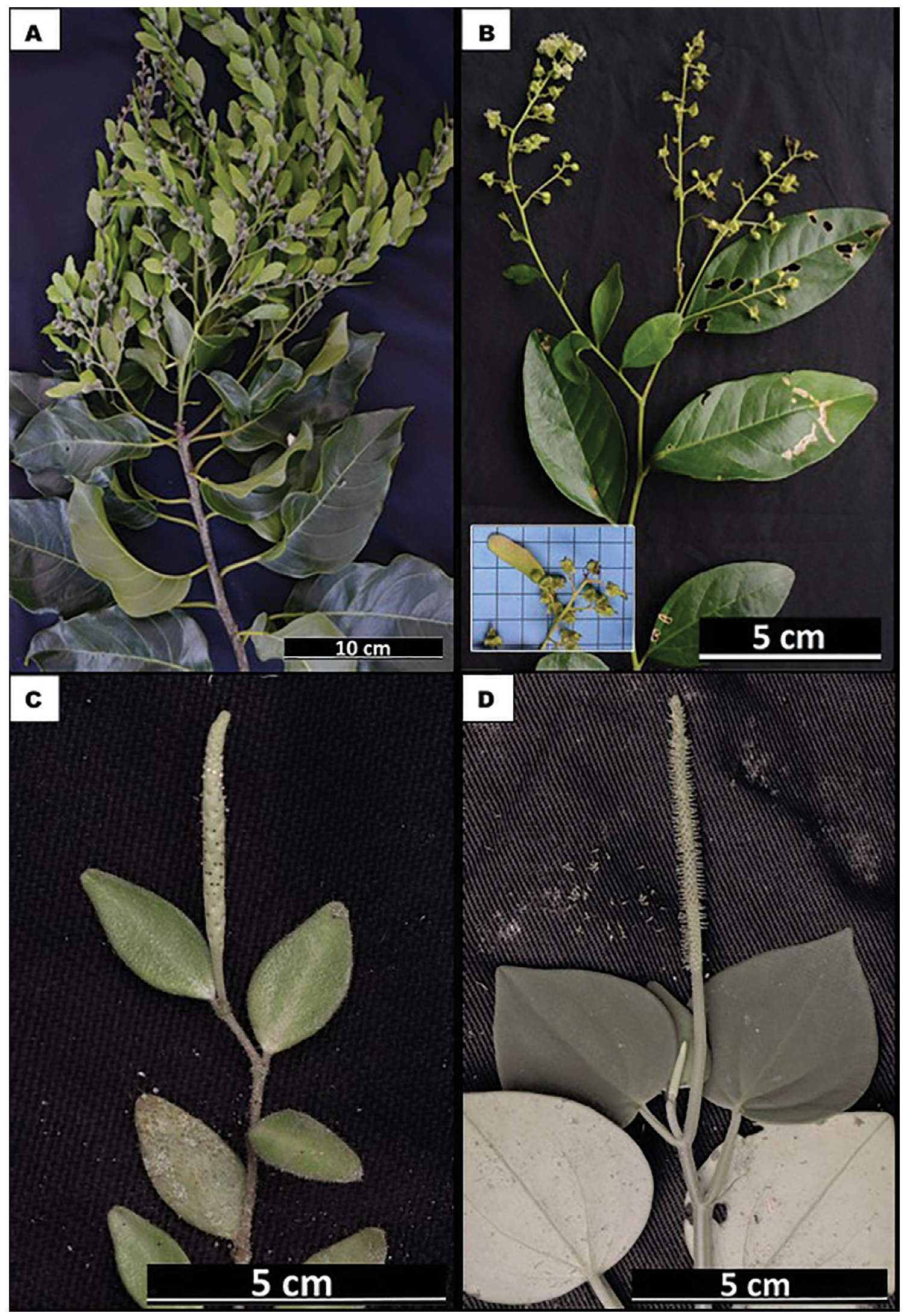

Figure 19. Phytolaccaceae: (A) Gallesia integrifolia; (B) Seguieria langsdorffii, details of the inflorescence and fruits are highlighted. Piperaceae: (C) Peperomia pseudoestrellensis; (D) Peperomia urocarpa. 


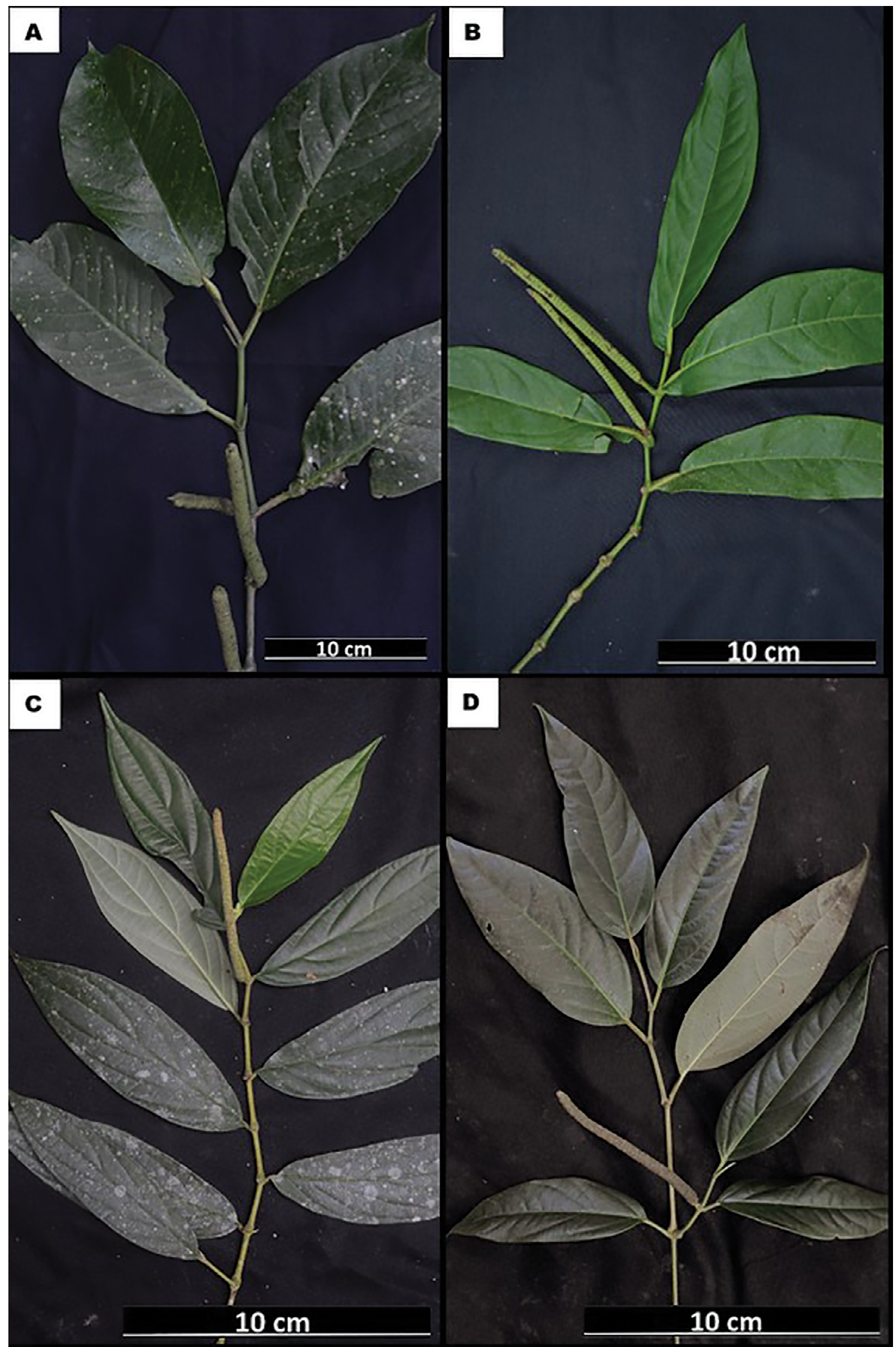

Figure 20. Piperaceae: (A) Piper amplum; (B) Piper arboreum; (C) Piper hispidum; (D) Piper lepturum. 


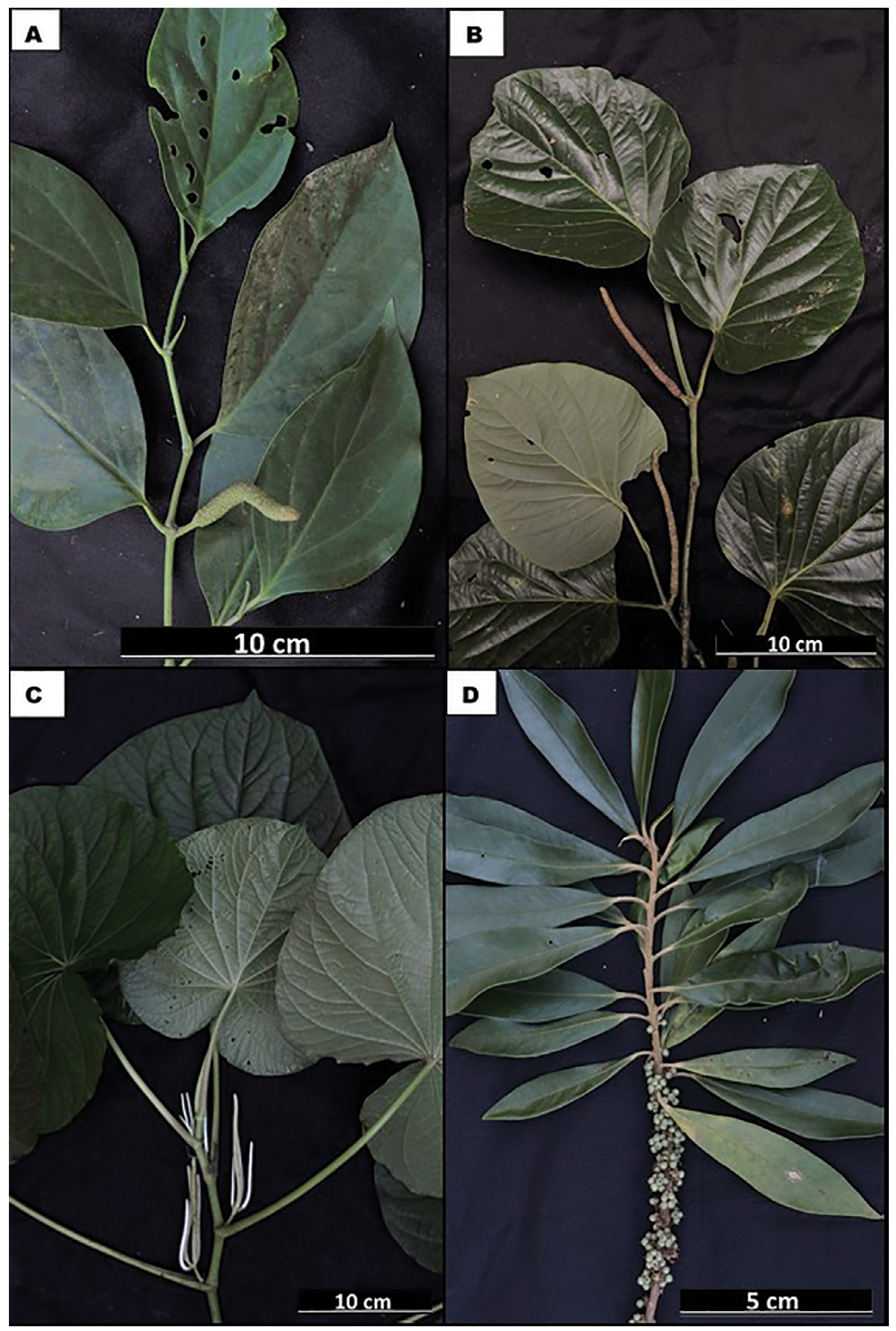

Figure 21. Piperaceae: (A) Piper rivinoides; (B) Piper solmsianum; (C) Piper umbellatum. Primulaceae: (D) Myrsine coriaceae. 

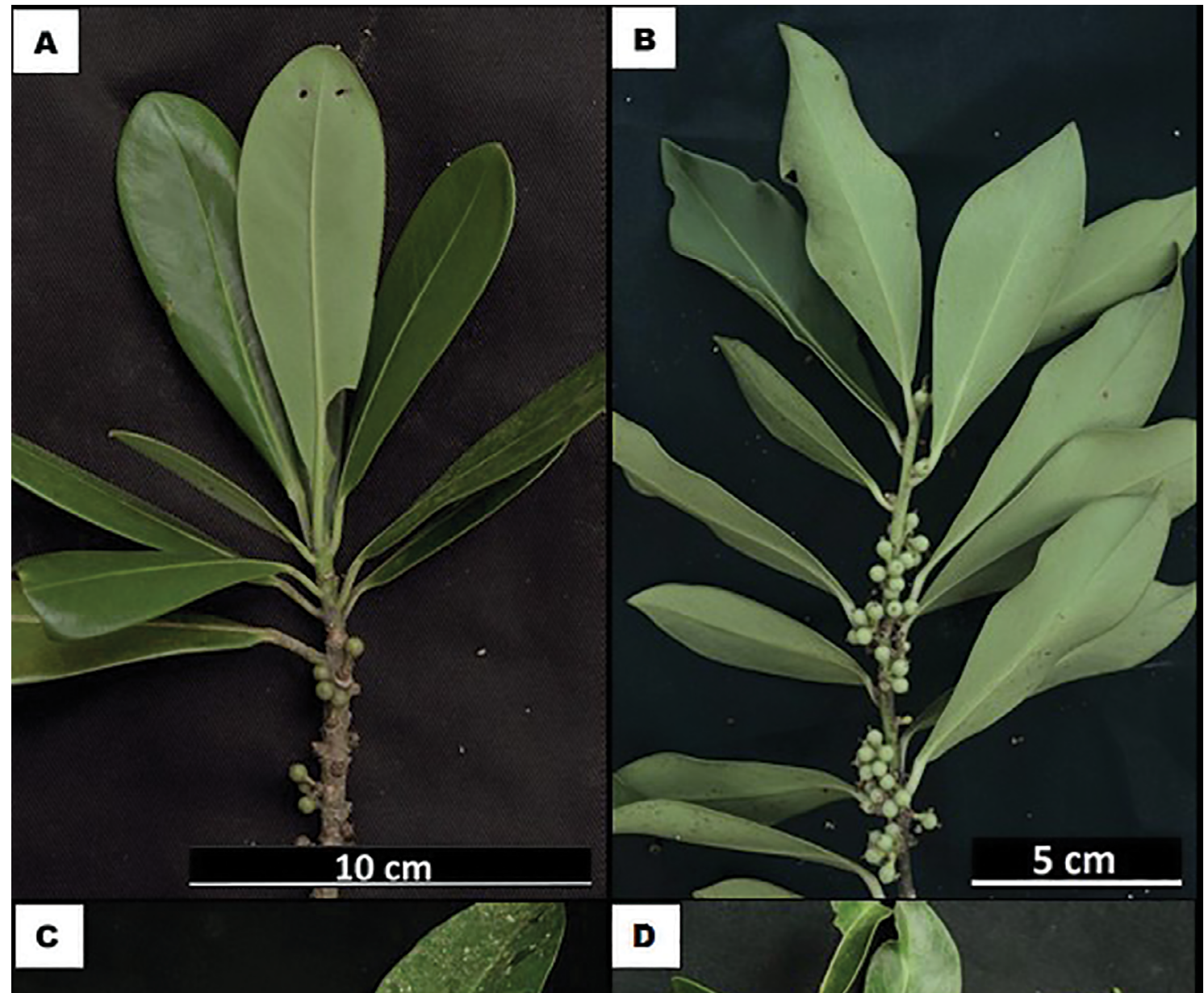


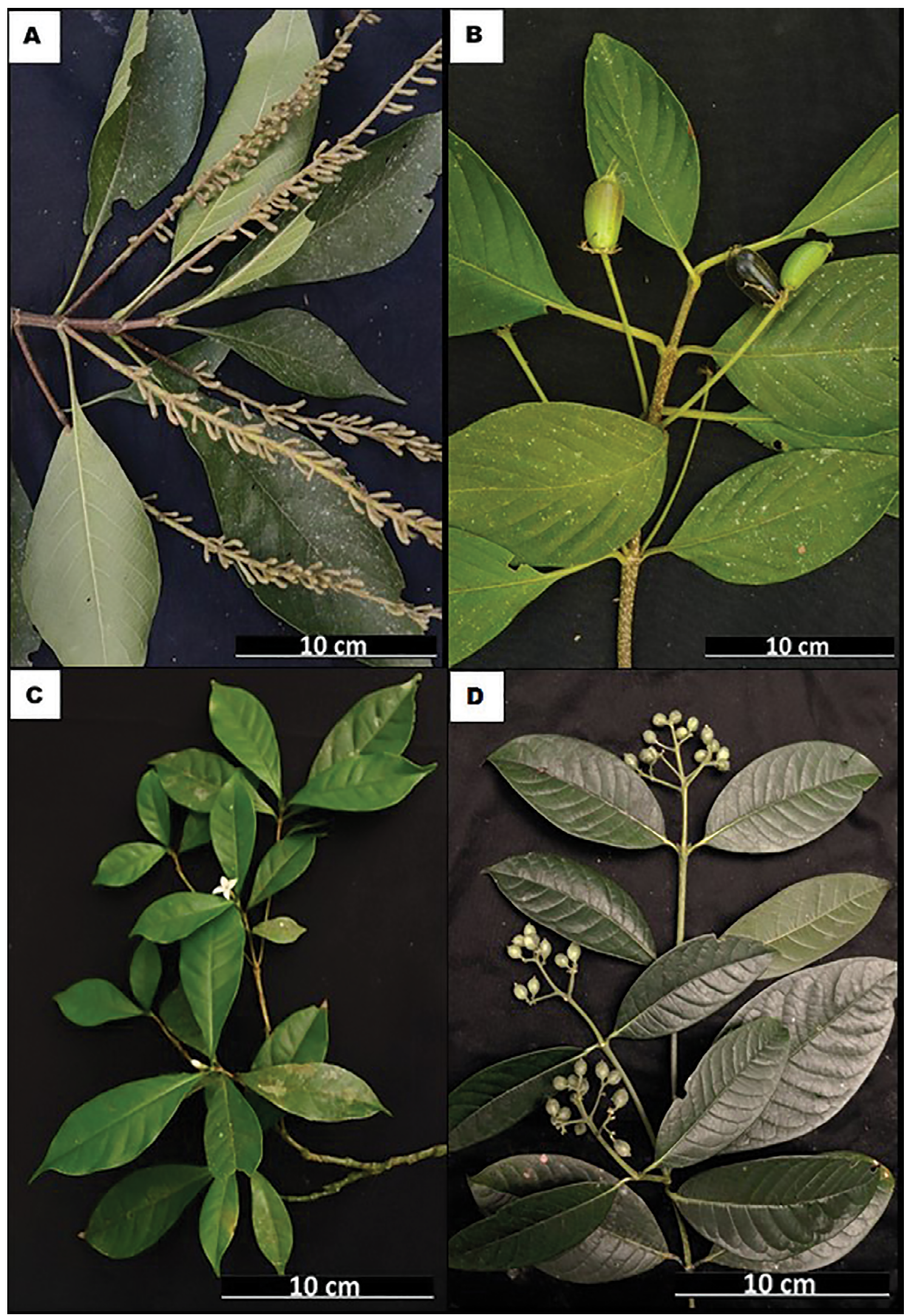

Figure 23. Rubiaceae: (A) Alseis floribunda; (B) Chomelia pedunculosa; (C) Cordiera myrciifolia; (D) Coussera meridionalis. 


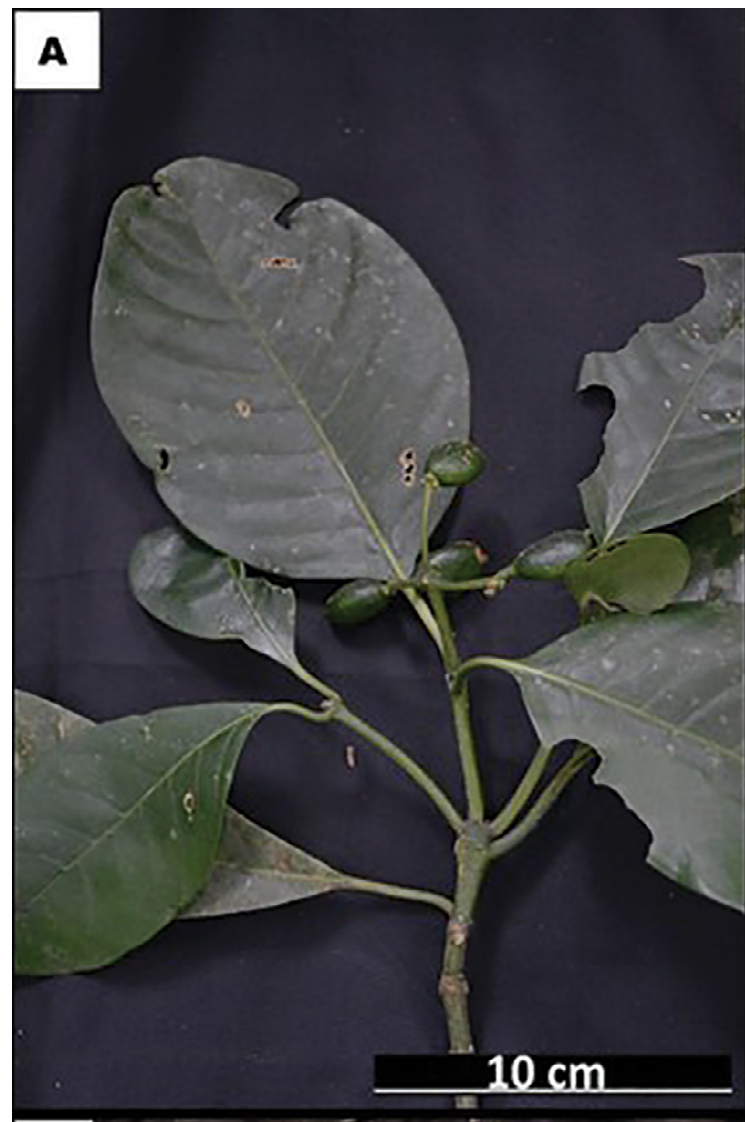

\section{B}

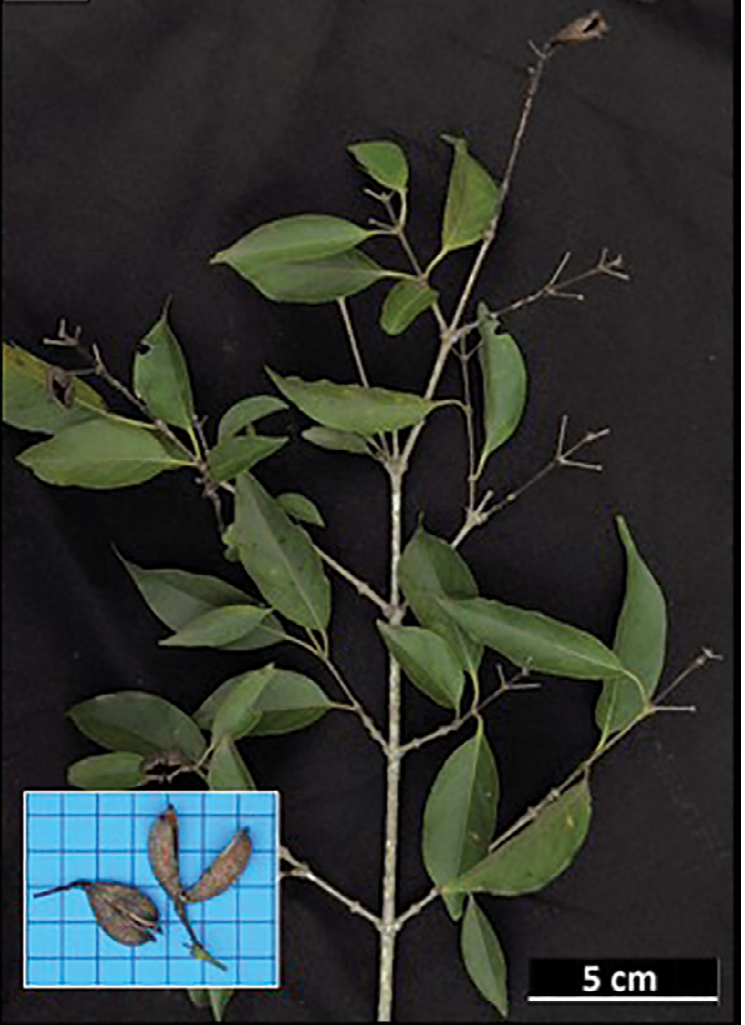

\section{C}

D

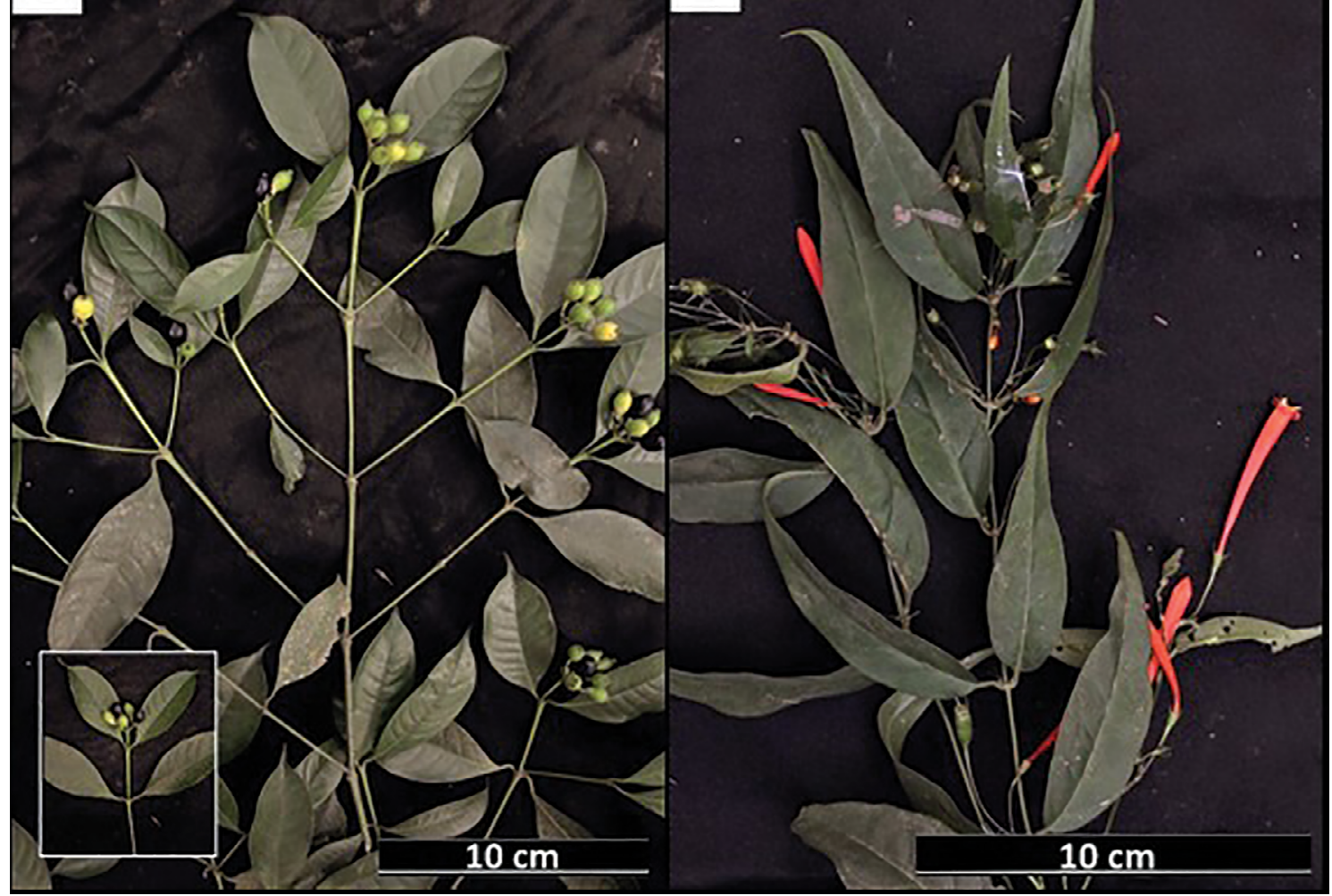

Figure 24. Rubiaceae: (A) Coussarea nodosa; (B) Coutarea hexandra, details of the fruits are highlighted; (C) Faramea truncata; (D) Manettia gracilis. 


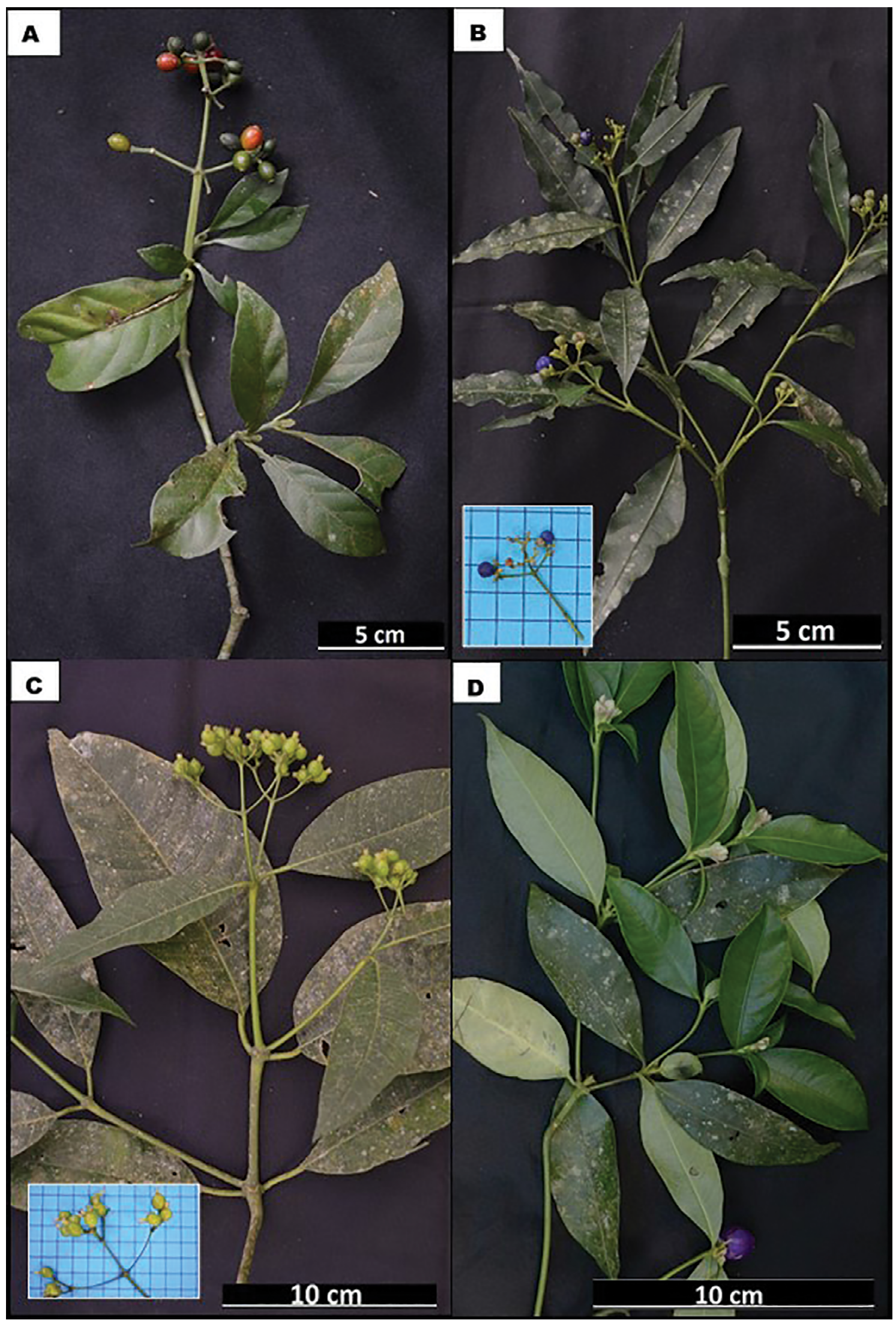

Figure 25. Rubiaceae: (A) Psychotria carthagenensis; (B) Psychotria leiocarpa, details of the fruits are highlighted; (C) Psychotria patentinervia, details of the fruits are highlighted; (D) Psychotria suterella. 


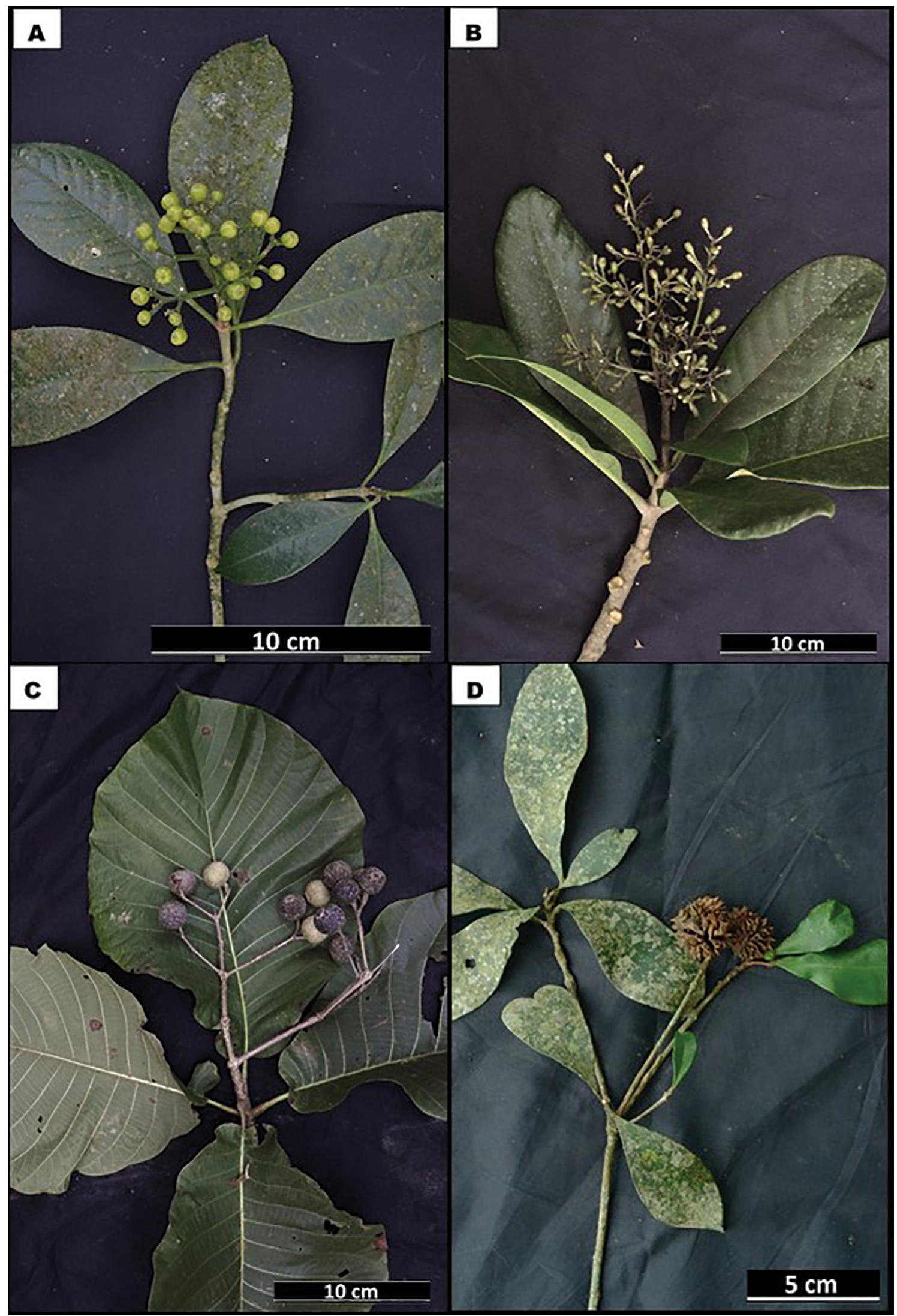

Figure 26. Rubiaceae: (A) Rudgea jasminoides; (B) Rustia Formosa; (C) Simira glaziovii. Rutaceae: (D) Esenbeckia grandiflora. 


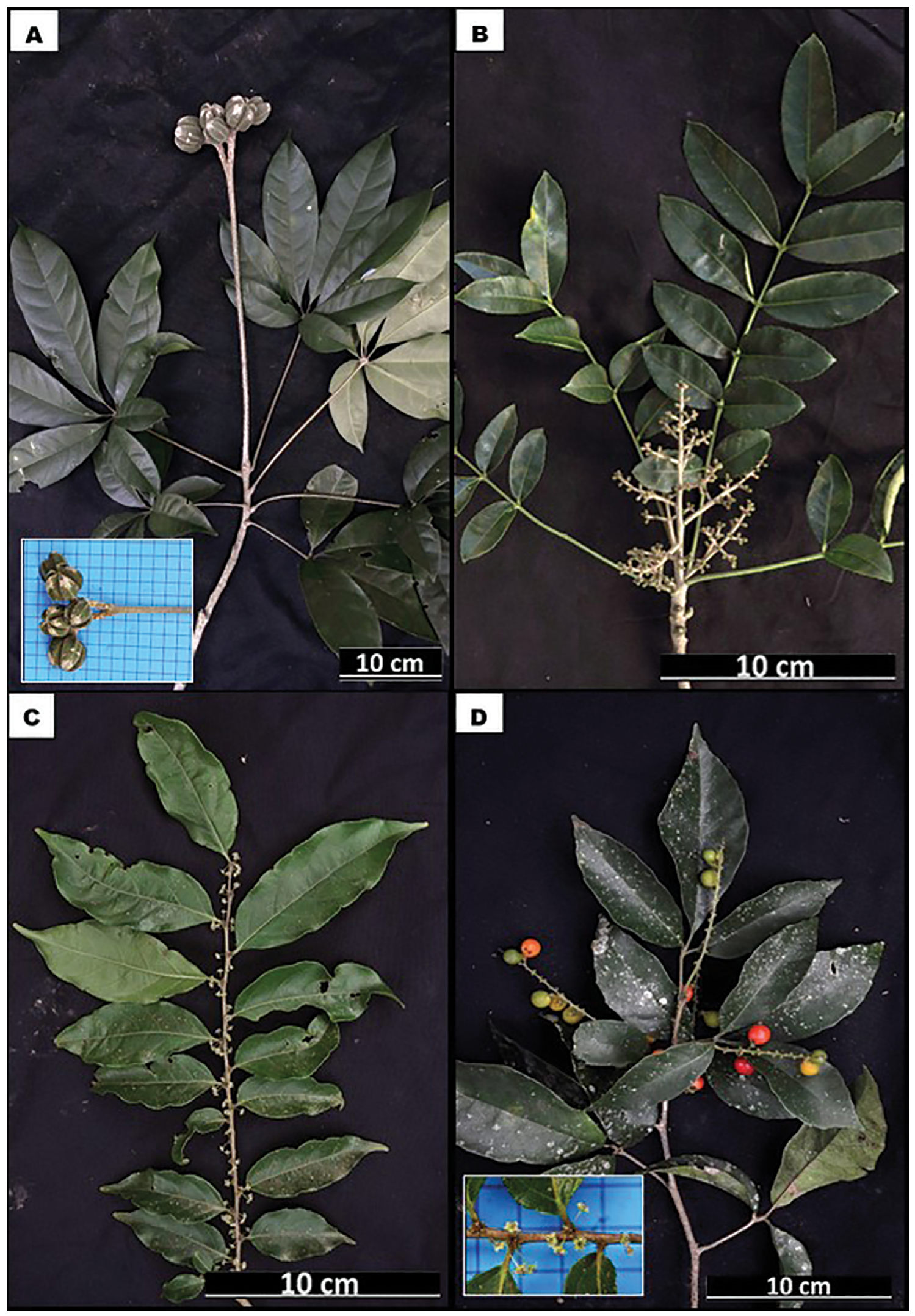

Figure 27. Rutaceae: (A) Neoraputia magnifica, details of the fruits are highlighted; (B) Zanthoxylum caribaeum. Salicaceae: (C) Casearia sylvestris, details of the inflorescence are highlighted. Sapindaceae: (D) Allophylus petiolulatus. 


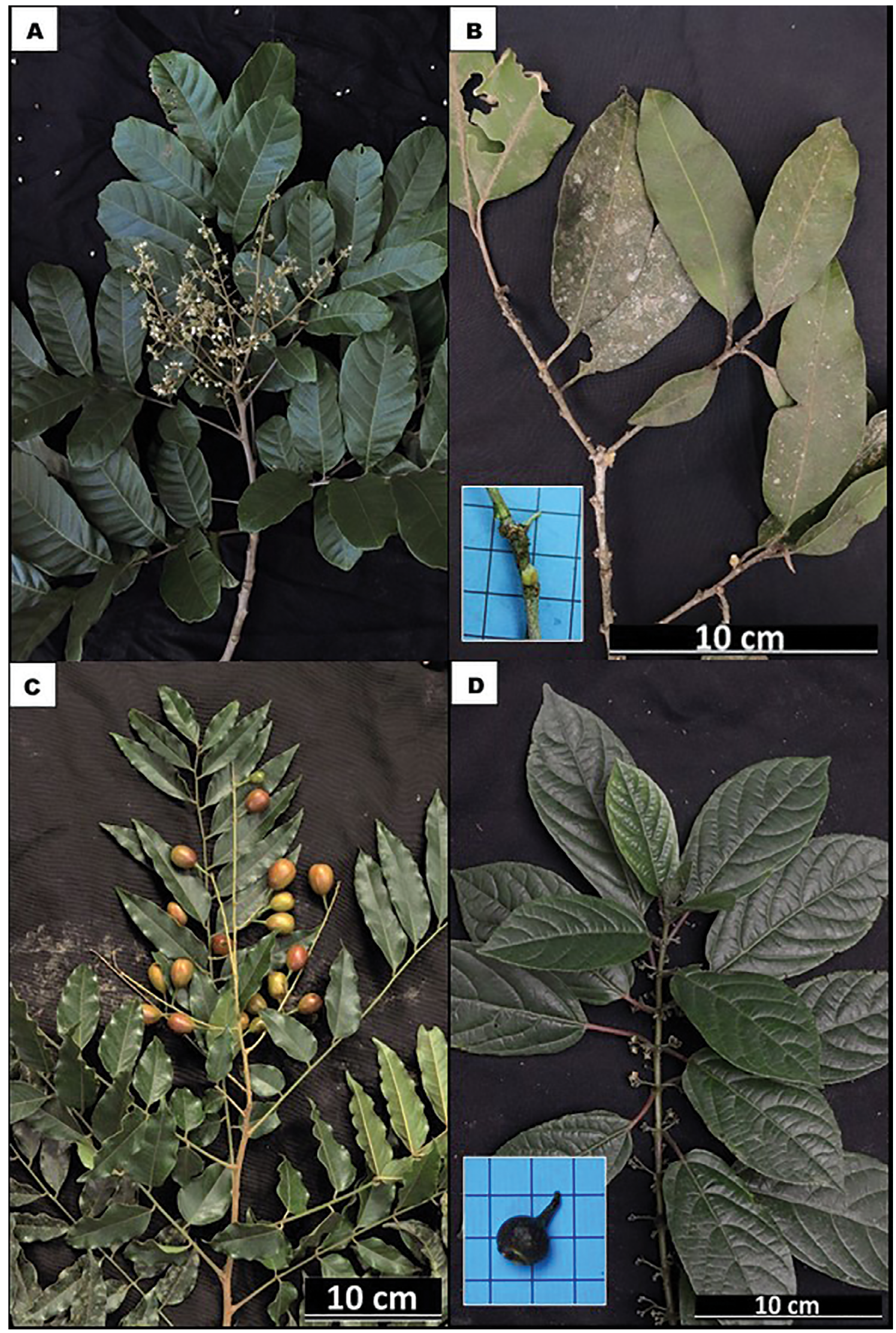

Figure 28. Sapindaceae: (A) Cupania oblongifolia, details of the inflorescence are highlighted. Sapotaceae: (B) Pouteria venosa, details of the inflorescence are highlighted. Simaroubaceae: (C) Picramnia cilata. Siparunaceae: (D) Siparuna brasiliensis, details of the fruits are highlighted. 


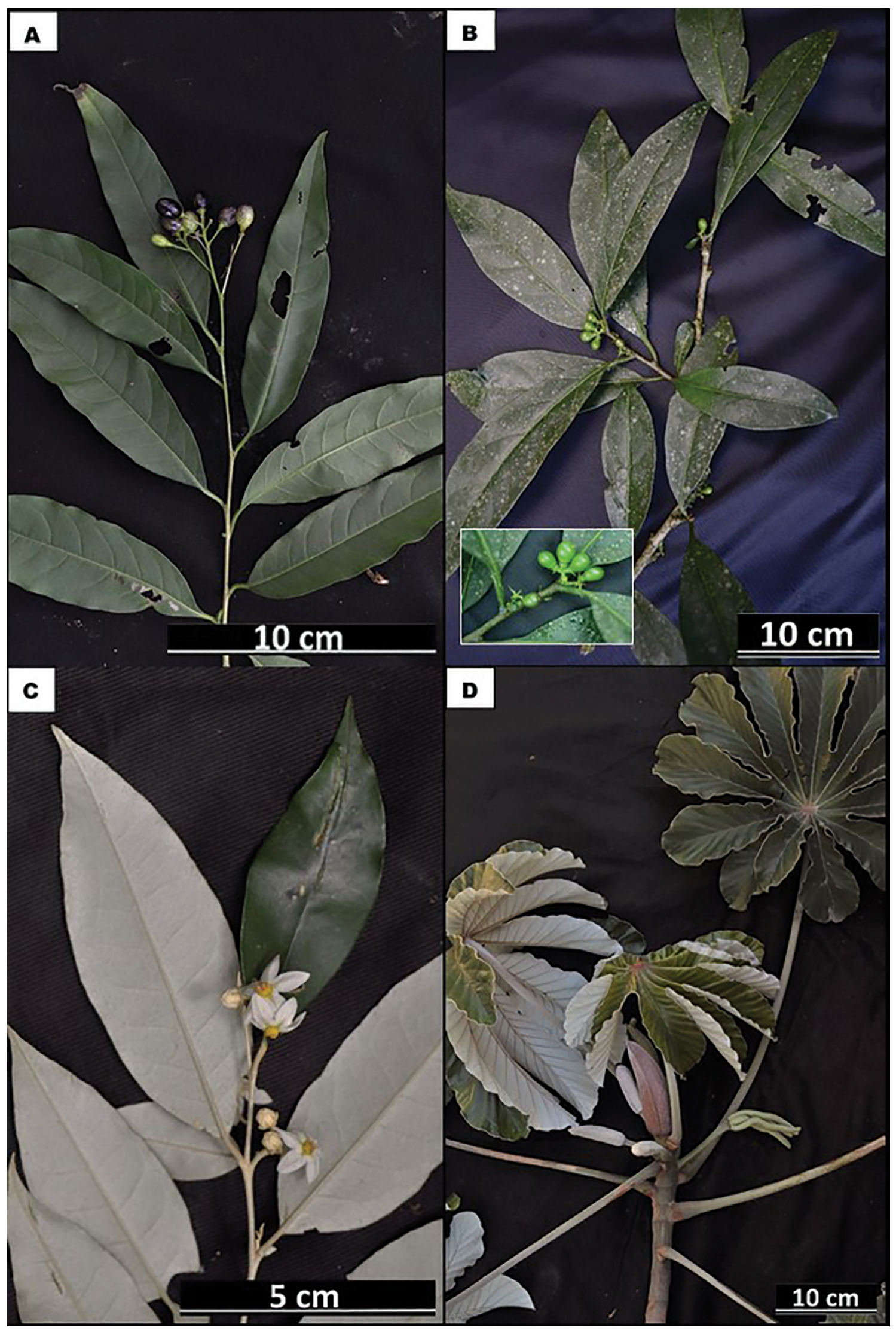

Figure 29. Solanaceae: (A) Cestrum intermedium; (B) Cestrum schlechtendalii, details of the fruits are highlighted; (C) Solanum swartzianum. Urticaceae: (D) Cecropia pachystachya. 


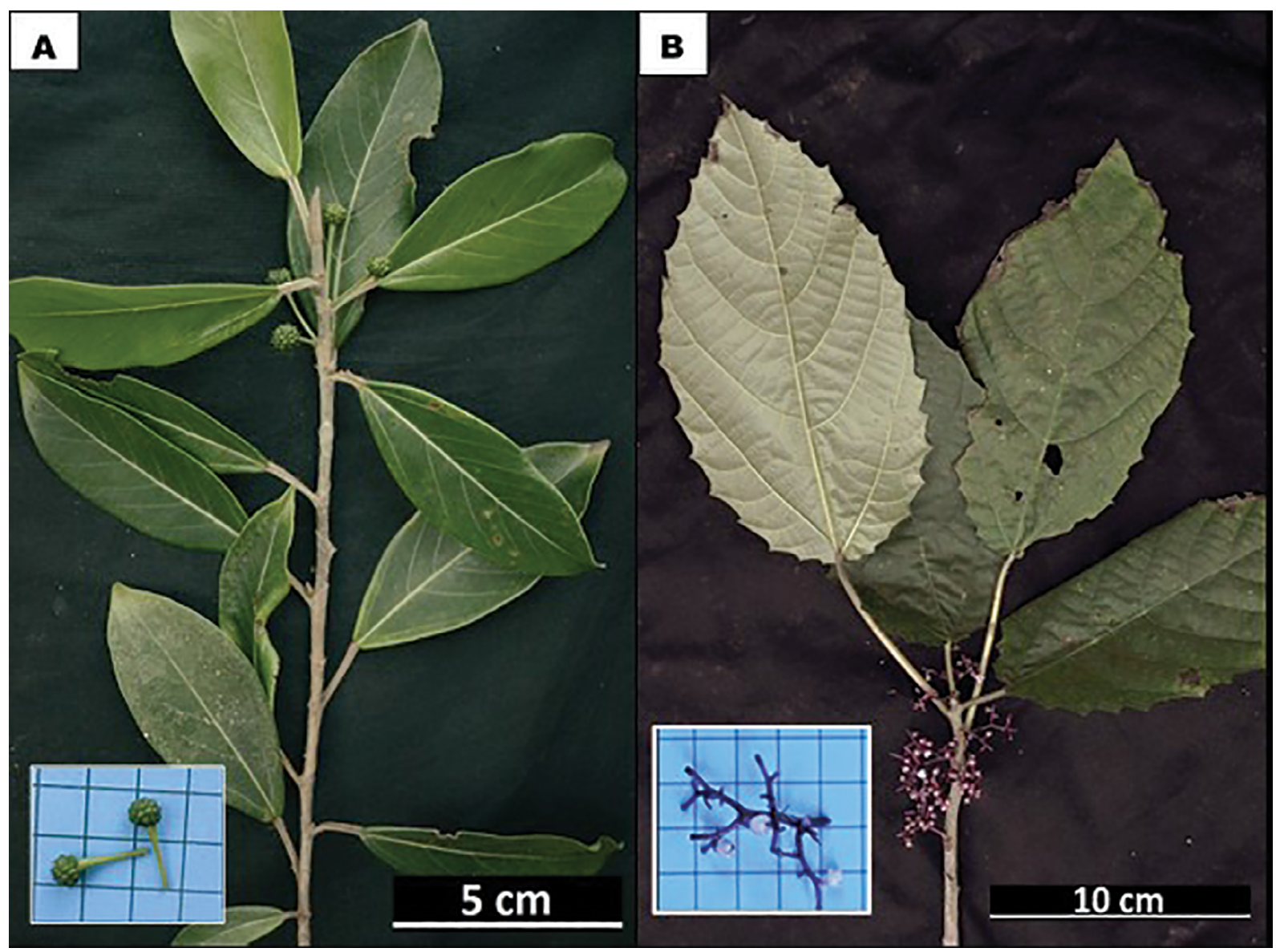

Figure 30. Urticaceae: (A) Coussapoa microcarpa, details of the fruits are highlighted; (B) Urera nitida, details of the inflorescence are highlighted.

\section{Acknowledgements}

To the employees at the operational base of the PEIb: João Batista Dias, Winny Luiz Midoes da Silva, Paulo Roberto dos Santos Souza, Marcos Aurélio Alves do Nascimento, Dorival Roberto dos Santos, José Francisco dos Santos, Aguinaldo dos Santos, José Cláudio Lucas da Silva, João Ivomar de Araújo, and Park Manager Joana Fava Cardoso Alves. To COTEC, which gave us the authorization to collect materials, $\mathrm{n}^{\circ}$ 015.717/2012. The Universidade Presbiteriana Mackenzie and Universidade Estadual Paulista (UNESP). Halph Alberghini for all the help during the field expeditions. To the taxonomists, for making identifications: Adriana Lobão (Annonaceae), Marcelo Monge (Asteraceae), Leonardo Biral dos Santos (Celastraceae), Julio A. Lombardi (Celastraceae), Gerson Oliveira Romão (Clethraceae), Letícia Lima (Euphorbiaceae), Ines Cordeiro (Euphorbiaceae), Vidal Mansano (Fabaceae), Rubens Queiroz (Fabaceae), Vinicius Castro Souza (Fabaceae), João Batista Baitello (Lauraceae), Fabrício Schmitz Meyer (Melastomataceae), Renato Goldenberg (Melastomataceae), Marcelo Reginato (Melastomataceae), João Aurelio Pastore (Meliaceae), Livia Ribeiro de Mendonça (Moraceae), Fiorella Fernanda Mazine Capelo (Myrtaceae), Osny T. Aguiar (Myrtaceae), Francisco Souza (Nyctaginaceae), Daniele Monteiro (Piperaceae), Maria De Fátima Freitas (Primulaceae), Marcelo A. de Pinho Ferreira (Rubiaceae), Marcela Firens (Rubiaceae), Jose Rubens Pirani (Rutaceae), Katia Freire da Silva (Sapindaceae) and Geraldo Antonio Daher Corrêa Franco (Generalista).

\section{Supplementary Material}

The following online material is available for this article: Identification key 1 Identification key 2 Identification key 3

\section{Author Contributions}

Andrea Garafulic Aguirre: substantial contribution in the concept and design of the study; contribution to data collection, analysis, interpretation, and manuscript preparation.

Juliana Teixeira: substantial contribution in the concept and design of the study; contribution to data collection, analysis, interpretation, and manuscript preparation.

João Paulo Fernandes Zorzanelli: substantial contribution in the concept and design of the study, data analysis, interpretation and manuscript preparation.

Gabriel Dalla Colletta: contribution to data collection, analysis and interpretation.

Daniela Sampaio: contribution to manuscript preparation and critical revision, adding intelectual content. 


\section{Conflicts of interest}

The authors declare that they have no conflict of interest related to the publication of this manuscript.

\section{References}

ALVARES CA; STAPE JL; SENTELHAS PC; GONÇALVES JLM; SPAROVEK G. 2013. Köppen'sclimate classification map for Brazil. Meteorologische Zeitschrift 22(06):711-728.

APG IV. 2016. An update of the Angiosperm Phylogeny Group classification for the orders and families of flowering plants. Botanical Journal of the Linnean Society 181(01): p.1-20.

BITTRICH, V.; SOUZA, C.S.D.; COELHO, R.L.G.; MARTINS, M.V.; HOPKINS, M.J.G.; AMARAL, M.C.E. 2012.An interactive key (Lucid) for the identifying of the genera of seed plants from the Ducke Reserve, Manaus, AM, Brazil. Rodriguésia 63(1):p.55-64.

BOVINI, M.G., FARIA, M., OLIVEIRA, R.R. \& KURTZ, B.C. 2014. Floristic diversity of the Cagarras Islands Natural Monument, Rio de Janeiro, Brazil. Check List 10(2):p.366-373.

BRAJE, T. J. et al. 2017. Archaeology, historical ecology and anthropogenic island ecosystems. Environmental Conservation 44(3):p.1-12.

BRAZ, D. M.; MOURA, M. V. L. P.; ROSA, M. M. T. DA. 2004. Identification key for woody species of an Atlantic Rain Forest remnant, in the Southeast of Brazil, based on vegetative characters. Acta Botanica Brasilica 18(2):p.225240.

BROOKS, T. M. et al. 2006. Global Biodiversity Conservation Priorities. Science 313(5183):58-61.

CALLADO, C.H., BARROS, A.A.M., RIBAS, L.A., ALBARELLO, N., GAGLIARDI, R. \& JASCONE, C.E.S. 2009. Flora e cobertura vegetal. In O ambiente da Ilha Grande (M. Bastos \& C.H. Callado, orgs.). UERJ, CEADS, Rio de Janeiro, p.91-161.

DUARTE, A. R. 2003. Espécies de myrtaceae de uma parcela permanente de floresta ombrófila densa baixo montana no parque estadual Carlos Botelho, município de Sete Barras - SP. Tese de Doutorado, Universidade de São Paulo, Escola Superior de Agricultura de Agricultura Luiz de Queiroz, Piracicaba.

ELTINK, M.; RAMOS, E.; TORRES, R.B.; TAMASHIRO, J.Y.; GALLEWMBECK, E. E KIMURA, E. 2011. Chave de identificação de espécies do estrato arbóreo da Mata Atlântica em Ubatuba (SP), com base em caracteres vegetativos. Biota Neotropica 11(2): http://www.biotaneotropica. org.br/v11n2/pt/abstract?identification-key+bn02511022011 (last acess on 12/10/2017).

FERREIRA. A. L.; COUTINHO, B.R.; PINHEIRO, H.T.; THOMAZ, L.D. 2007. Composição florística e formações vegetais da Ilha dos Franceses, Espírito Santo. BOL. MUS. BIOL. MELLO LEITÃO 22:25-44.

GALETTI, M. et al. 2016. Defaunation and biomass collapse of mammals in the largest Atlantic forest remnant. Animal Conservation 20(3):p.270-281.

GIBSON, L. A. et al. 2017. Island refuges: conservation significance of the biodiversity patterns resulting from "natural" fragmentation. Biological Conservation 212(A): p.349-356.

GONÇALVES, E.G.; LORENZI, H. 2007. In: Morfologia Vegetal, edi. Instituto Plantarum.

HADDAD, N. M. et al. 2015. Habitat fragmentation and its lasting impact on Earth's ecosystems. Science Advances 1(2): p.1-9.

HARRIS, J.G. \& HARRIS, M.W. 1994. Plant identification terminology: an illustrate glossary. Spring Lake Publishing, Payson.

HASSEMER, G.; FERREIRA, P. M. A.; TREVISAN, R. 2015. A review of vascular plant endemisms in Santa Catarina, southern Brazil, highlights critical knowledge gaps and urgent need of conservation efforts. The Journal of the Torrey Botanical Society 142(1): p.78-95.

HOFMAN, C. A.; RICK, T. C. 2017. Ancient Biological Invasions and Island Ecosystems : tracking Translocations of Wild Plants and Animals. Journal of Archaeological Research (online first articles):1-51.
HOWTHORNE, W.D.; CABLE, S.; MARSHALL, C.A.M. 2014. Empirical trials of plant field guides. Conservation Biology 28(3):p.654-662.

INSTITUTO BRASILEIRO DE GEOGRAFIA E ESTATÍSTICA(IBGE). 2012, Manual técnico da vegetação brasileira. Instituto Brasileiro de Geografia e Estatística. Rio de Janeiro, 275p.

IUCN. 1997. Centres of plant diversity: a guide and strategy for their conservation. Vol.3 ed. Cambridge, UK: World Wide Fund for Nature (WWF) and ICUN - World Conservation Union.

IUCN. 2017. The IUCN red list of threatened species: version 2017-2. IUCN. http://www.iucnredlist.org/ (last access on 14/10/2017).

KIER, G. et al. 2009. A global assessment of endemism and species richness across island and mainland regions. Proceedings of the National Academy of Sciences 106(23):p.9322-9327.

KREFT, H. et al. 2008. Global diversity of island floras from a macroecological perspective. Ecology Letters 11(2):p.116-127.

KREFT, H.; JETZ, W. 2007. Global patterns and determinants of vascular plant diversity. Proceedings of the Royal Society of London B Series 104(14):p.5925-5930.

KURTZ, B. C., SOUZA, V. C., MAGAlHÃES, A. M., PAUlA-SOUZA, J., DUARTE, A. R., JOAQUIM-JR., G. O. 2017. The vascular flora and vegetation of Queimada Grande Island, São Paulo State, southeastern Brazil. Biota Neotropica. 17(4): e20170336. http://dx.doi.org/10.1590/1676-0611BN-2017-0336 (last acess on 10/11/2017).

LIMA, R. A. F.; MORI, D. P.; PITTA, G.; MELITO, M. O.; BELLO, C.; MAGNAGO, L. F.; ZWIENER, V. P.; SARAIVA, D. D.; MARQUES, M. C. M.; OLIVEIRA, A. A.; PRADO, P. I. 2015. How much do we know about the endangered Atlantic Forest? Reviewing nearly 70 years of information on tree community surveys. Biodiversity and Conservation 24: p.2135-2148.

LUBER, J.; TULER, A. C.; TORRES, F.; CHRIST, J. A.; GUIDONI-MARTINS, K. G.; ZANETTI, M.; HOLLUNDER, R. K.; MANHÃES, V. C.; ZORZANELLI, J. P. F.; MENDONÇA, E. S.; GARBIN, M. L.; CARRIJO, T. T. 2016. List of angiosperm species in an Atlantic Forest fragmente reveals collection gaps in Espirito Santo state, Brazil. Check List 12(1): 1835.

MARQUES, I. 2015. Teaching: Bury botany's outdated image. Nature 520(7547):p. 295-295.

MELHEM, T.S., WANDERLEY, M.G.L., MARTINS, S.E., JUNGMENDAÇOLLI, S.L., SHEPHERD, G.J. \& KIRIZAWA, M. 2007. Flora Fanerogâmica do Estado de São Paulo. FAPESP, São Paulo,v.5.

MARTINELLI, G., MORAES, M.A. 2013. Livro Vermelho da Flora do Brasil. Instituto de Pesquisas Jardim Botânico do Rio de Janeiro and Andrea Jakobson, Rio de Janeiro, $1100 \mathrm{p}$.

MYERS, N. et al. 2000. Biodiversity hotspots for conservation priorities. Nature 403(6772):p.853-858.

NOGUÉ, S. et al. 2017. Island biodiversity conservation needs palaeoecology. Nature Ecology \& Evolution 1(7):p.181.

NUNES-FREITAS, A.F.; ROCHA-PESSÔA, T.C.; DIAS, A.S.; ARIANI, C.V. AND ROCHA, C.F.D. 2009. Bromeliaceae da Ilha Grande: revisão da lista de espécies. Biota Neotropica 9(2): http://www.biotaneotropica.org. br/v9n2/pt/abstract?article+bn01209022009 ISSN 1676-0603 (last acess on $9 / 10 / 2017)$.

PRATA, E. M. B.; ASSIS, M. A.; JOLY, C. A. 2011. Composição florística e estrutura da comunidade arbórea na transição da floresta ombrófila densa das terras baixas - floresta ombrófila densa submontana do Núcleo Picinguaba/ PESM, Ubatuba, sudeste do Brasil. Biota Neotropica 11(2): http://www. biotaneotropica. org.br/v11n2/pt/abstract?inventory+bn02211022011 (last acess on 02/03/2018).

REJMANEK, M.; BREWER, S. W. 2001. Vegetative Identification of Tropical Woody Plants: State of the Art and Annotated Bibliography1. Biotropica 33(2):p. 214-228.

RIBEIRO, M.C.; METZGER, J.P.; MARTENSEN, A.C.; PONZONI, F.J.; HIROTA, M.M. 2009. The Brazilian Atlantic Forest: How much is left, and how is the remaining forest distributed? Implications for conservation. Biological Conservation 142: 1141-1153. 
ROCHELLE, A. L. C.; CIELO-FILHO, R.; MARTINS, F. R. 2011. Florística e estrutura de um trecho de floresta ombrófila densa atlântica submontana no Parque Estadual da Serra do Mar, em Ubatuba/SP, Brasil. Biota Neotropica 7(2): http://www.biotaneotropica.org.br/v11n2/en/abstract?inventory+ bn02711022011 (last acess on 02/03/2018).

ROMANINI, R. P. 2006. A família Orchidaceae no Parque Estadual da Ilha do Cardoso, Cananéia, SP. Dissertação de mestrado,Instituto de Botânica da Secretaria de Estado do Meio Ambiente, São Paulo.

SÃO PAULO. 2016. Resolution SMA n ${ }^{\circ}$ 57, 5 June 2016. Diário Oficial de São Paulo, edition 126 (120), section 1:55-57, 30 June 2016.

SOUZA, V.C.; LORENZI, H. 2008. In: Botânica sistemática, edit. Instituto Plantarum.

THIERS, B. 2017. Index Herbariorum: a global directory of public herbaria and associated staff. New York Botanical Garden's virtual herbarium. http:// sweetgum.nybg.org/ih/ (last acess on 4/10/2017).

TRIAS-BLASI, A.; VORONTSOVA, M. 2015. Botany: Plant identification is key to conservation. Nature 521(7551): p.161-161.

URBANETZ, C.; TAMASHIRO, J. Y.; KINOSHITA, L. S. 2010. Chave de identificação de espécies lenhosas de um trecho de Floresta Ombrófila Densa Atlântica, no Sudeste do Brasil, baseada em caracteres vegetativos. Biota Neotropica 10(2): http://www.biotaneotropica.org.br/v10n2/pt/ abstract?article+bn00910022010 ISSN 1676-0603 (last acess 03/10/2017).
WANDERLEY, M.G.L., SHEPHERD, G.J., GIULIETTI, A.M., MELHEM, T.S., BITTRICH, V. \& KAMEYAMA, C. 2002. Flora Fanerogâmica do Estado de São Paulo. HUCITEC, São Paulo,v.2.

WANDERLEY, M.G.L., SHEPHERD, G.J., MELHEM, T.S., GIULIETTI, A.M. \& KIRIZAWA, M. 2003. Flora Fanerogâmica do Estado de São Paulo. FAPESP, RiMa, São Paulo, v.3.

WANDERLEY, M.G.L., SHEPHERD, G.J., MELHEM, T.S., MARTINS, S.E., KIRIZAWA, M. \& GIULIETTI, A.M. 2005. Flora Fanerogâmica do Estado de São Paulo. FAPESP, RiMa, São Paulo,v.4.

WANDERLEY, M.G.L., SHEPHERD, G.J, MELHEM, T.S., GIULIETTI, A.M. \& MARTINS, S.E. 2009. Flora Fanerogâmica do Estado de São Paulo. FAPESP, São Paulo, v.6.

WANDERLEY, M.G.L., SHEPHERD, G.J, MELHEM, T.S., GIULIETTI, A.M. \& MARTINS, S.E. 2012. Flora Fanerogâmica do Estado de São Paulo. Instituto de Botànica, São Paulo, v.7.

WANDERLEY, M.G.L., SHEPHERD, G.J, MELHEM, T.S., GIULIETTI, A.M. \& MARTINS, S.E. 2016. Flora Fanerogâmica do Estado de São Paulo. Instituto de Botànica, São Paulo, v.8.

ZORZANELLI, J. P. F.; DIAS, H. M.; SILVA, A. G.; KUNZ, S. H. 2017. Vascular plant diversity in a Brazilian hotspot: floristic knowledge gaps and tools for conservation. Brazilian Journal of Botany 40(3): p.819-827.

Received: $11 / 12 / 2017$

Revised: 05/06/2018

Accepted: 26/07/2018

Published online: $23 / 08 / 2018$ 